University of California, Hastings College of the Law UC Hastings Scholarship Repository

Faculty Scholarship

2002

\title{
Consumption Taxes and the Theory of General and Individual Taxation
}

Robin Feldman

UC Hastings College of the Law, feldmanr@uchastings.edu

Follow this and additional works at: https://repository.uchastings.edu/faculty_scholarship

Part of the Taxation-State and Local Commons

\section{Recommended Citation}

Robin Feldman, Consumption Taxes and the Theory of General and Individual Taxation, 21 Va. Tax Rev. 293 (2002).

Available at: https://repository.uchastings.edu/faculty_scholarship/159

This Article is brought to you for free and open access by UC Hastings Scholarship Repository. It has been accepted for inclusion in Faculty Scholarship

by an authorized administrator of UC Hastings Scholarship Repository. For more information, please contact wangangela@uchastings.edu. 


\section{Faculty Publications \\ UC Hastings College of the Law Library}

Author: Robin Cooper Feldman

Source: Virginia Tax Review

Citation: 21 Va. Tax Rev. 293 (2002).

Title: $\quad$ Consumption Taxes and the Theory of General and Individual Taxation

Originally published in VIRGINIA TAX REVIEW. This article is reprinted with permission from VIRGINIA TAX REVIEW and University of Virginia School of Law. 


\title{
VIRGINIA TAX REVIEW
}

VOLUME 21, NUMBER 3

Winter 2002

\author{
CONSUMPTION TAXES AND THE THEORY OF \\ GENERAL AND INDIVIDUAL TAXATION
}

Robin Cooper Feldman *

\section{TABLE OF CONTENTS}

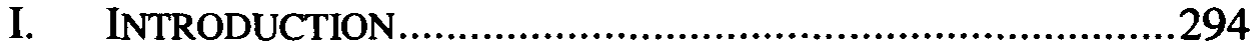

II. GENERAL AND INDIVIDUAL TAXATION ..........................299

III. The PhILOSOPHICAL ROOTS OF MODERN TAX

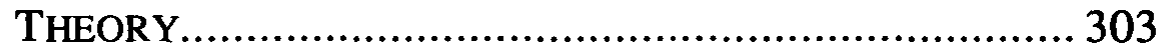

IV. Tax Policy ARguments IN General...................... 315

A. Applying the Tax Policy Arguments: A Sleep Tax... 316

B. Which Tax Policy Arguments Could Support a System Regardless of How Well it Captures Individual Taxation?

V. CONSUMPTION TAX THEORY …............................. 322

*Stanford Law School, Lecturer in Law. J.D. Stanford Law School. B.A. Stanford University. I am grateful beyond measure to Alan Auerbach, Joe Bankman, Jeremy Bulow, Richard Craswell, Yossi Feinberg, Tom Grey, Joe Grundfest, Don Herzog, Edward Hymson, Calvin Johnson, Mark Kelman, Marcia Mayer, Roger Noll, and Richard Schmalbeck for their comments on prior drafts and to Suraj Jacob for research assistance. I am also indebted to Charles McLure, Peggy Radin, Steve Salop, Jeff Strnad, and Jeffrey Zwiebel. 


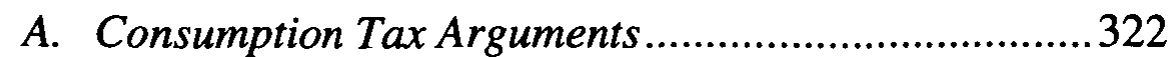

B. Consumption Tax Arguments: The Philosophical Roots.

C. Which Consumption Tax Arguments Could Support a System Regardless of How Well it Captures Individual Consumption?............................................334

VI. IMPLEMENTING CONSUMPTION TAXES ….......................337

A. The Mechanics of Taxing Consumption.......................337

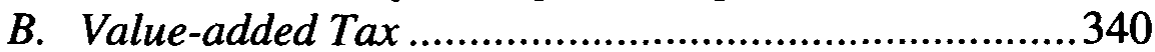

C. Regressivity: A Problem for VATs and Retail Sales

Taxes..........................................................................341

D. The Modern Consumption Tax Proposals ...................343

1. Operation of Proposals...........................................344

2. Borrowing Under the Modern Proposals ...............345

VII. HOW THE MODERN PROPOSALS FAIL TO TAX INDIVIDUAL CONSUMPTION

A. Immediate Expensing if the Firm-Level Tax is Fully

Shifted. 348

B. Immediate Expensing if the Firm-Level Tax is Not Ordinarily Shifted.

1. Conventional Wisdom on Profits Taxes ................352

2. Conventional Wisdom Applied to the Modern Proposals

C. Would Immediate Expensing Move the System

Towards General Taxation?...

D. Other Forms of Consumption Taxes.

VIII.CONCLUSION 358

IX. ISSUES FOR FUTURE CONSIDERATION 359

\section{INTRODUCTION}

What does it mean when a particular tax plan is described as taxing consumption? Does it mean that the plan would tax individuals for the value of what they have consumed? Although, one might reasonably assume this is true, consumption taxes need not always produce a strong correlation between tax burdens and levels of consumption.

Consider, for example, an extreme case. Suppose we decide to levy a tax of $30 \%$ on all goods consumed during the year. The taxing authorities could add up the value of all of the goods consumed during the year, divide that by the number of goods consumed, and charge each buyer a standandvameunt of tax on each purchase. With 
a standard consumption tax of $\$ 100$, for example, consumers would pay $\$ 100$ on the purchase of a tricycle and $\$ 100$ on the purchase of a Mercedes. Such a system would tax the activity of consumption and would succeed in collecting the appropriate percentage of the nation's consumption from consumers. It would not, however, do a very good job of taxing individuals for the value of what they have consumed.

I will use the term individual taxation to refer to the concept described above. Specifically, individual taxation occurs when a tax system correlates an individual's tax bill to that person's share of the tax base. I do not mean to suggest that individual taxation occurs only when tax bills reflect each person's share of the tax base with absolute precision. No tax system is perfect, and deviations inevitably occur. For example, a system may fail to tax individuals on their full level of the taxed activity because the administrative burden of complete collection would be too great. The system also may deviate from complete taxation in an effort to accommodate goals other than those related to taxing the base. In addition, although taxing authorities may intend to tax those engaged in the activity of the base, taxpayers may be able to shift the burden onto other players in the system.

When shifting and leakages occur, however, one should ask how the deviations affect tax burdens for those who participate in the activity of the base. It is possible that although taxpayers escape some taxation, the resulting burdens represent a rough approximation of the taxpayers' shares of the taxed activity. Such a system would still result in individual taxation, given that tax burdens reasonably correlate with each taxpayer's share of the base. Under other circumstances, the system may shift burdens among those who participate in the activity of the base such that some taxpayers pay more than their share and others pay less. Such deviations would move a system towards what I term general taxation. General taxation occurs when the government taxes the base throughout society as a whole but does not necessarily tax individuals for their actual share of the base. Finally, it is possible that in deviating from taxing citizens for the value of what they have consumed, the system results in neither individual nor general taxation.

Does it matter if a tax system deviates from individual taxation? The answer depends on the underlying theories advanced in support of the tax system. If the theories do not depend on individual taxation, deviations are irrelevant. If the underlying theories depend on individual taxation, however, the more the system deviates from individual taxation, the less the system can satisfy the foundational 
logic. In those circumstances, one should ask if other tax systems could produce a closer match between the theories and the effects.

This article applies the concepts of general and individual taxation to consumption taxes. Current academic literature devotes considerable attention to consumption tax proposals, " with much of the attention focused on a series of tax plans that are related in their design. $^{2}$ All of the proposals were derived by manipulating the details of a value-added tax (VAT).

Commentators generally view consumption taxes as good for the economy ${ }^{3}$ and more simple than income taxes ${ }^{4}$ but regressive. ${ }^{5}$ Thus,

1 See Anne Alstott, Colloquium on Wealth Transfer Taxation: The Uneasy Liberal Case Against Income and Wealth Transfer Taxation: A Response to Professor McCaffery, 51 TAX L. REV. 363 (1996) (consumption taxation enjoying renewed political popularity); David F. Bradford, Consumption Taxes: Some Fundamental Transition Issues, in FRONTIERS OF TAX REFORM 123, 123 (Michael J. Boskin ed., 1996) (noting current interest in shifting to a consumption-based tax system). Recent articles discuss how various groups of taxpayers would be affected by a shift to a consumption tax, whether consumption tax proposals would be as simple as proponents claim, and how different sectors of the economy would fare if the United States shifted to a consumption tax. See David Altig, Alan J. Auerbach, Laurence J. Kotlikoff, Kent A. Smetters \& Jan Walliser, Simulating Fundamental Tax Reform in the U.S., 91 AM. ECO. REv. 574 (2001) (simulating effects on economic output and distribution); Kenneth L. Judd, The Impact of Tax Reform in Modern Dynamic Economies, in TRANSITION COSTS OF FUNDAMENTAL TAX REFoRM 5-6 (Kevin A. Hassett \& R. Glenn Hubbard eds., 2001); David A. Weisbach, Ironing Out the Flat Tax, 52 STAN. L. REV. 599, (2000) (evaluating simplicity gains of shifting to consumption tax); ECONOMIC EFFECTS OF Fundamental TAX Reform (Henry J. Aaron \& William G. Gale eds., 1996). See also Edward J. McCaffery, The Uneasy Case for Wealth Transfer Taxation, 104 YALE L.J. 283 (1996) (advocating consumption tax plus wealth tax as approach consistent with liberalism).

2 The most prominent of these plans is the Flat Tax, which was originally described by Hall and Rabushka, introduced in Congress by House Majority Leader Richard Armey and Senator Richard Shelby and touted by presidential candidate Steve Forbes. See Robert E. Hall \& Alvin RabushKa, The Flat TaX (2nd ed., 1995). The bill was introduced in the House by Congressman Armey in 1994 and in the Senate by Senator Shelby in 1995 and has been reintroduced by the two members of Congress in subsequent sessions. See, e.g., H.R. 1040, 105th Cong. (1997). See also Alan J. Auerbach, Tax Reform, Capital Allocation, Efficiency, and Growth, in ECONOMIC EFFECTS OF FUNDAMENTAL TAX REFORM 29, 44 (Henry J. Aaron \& William G. Gale eds., 1996). A variation on the Hall/Rabushka Flat Tax is Bradford's "X" Tax. See Altig et al., supra note 1, at 575 (describing Bradford's $X$ Tax). In addition, McLure and Zodrow have proposed hybrid systems for the United States as well as for developing countries. See Charles E. McLure, Jr. \& George R. Zodrow, A Hybrid Approach to the Direct Taxation of Consumption, in FRONTIERS OF TAX REFORM 70 (Michael J. Boskin ed., 1996).

3 See, e.g., sources cited infra note 76.

4 See infra notes 88-90 and accompanying text.

5 See infra notes 110-16 and accompanying text. 
if the United States were to shift from an income tax to a consumption tax, the wealthy would benefit while the poor would suffer greater tax burdens.

The modern proposals offer the tantalizing claim that they are good for the economy, maintain simplicity, and can also address regressivity. Thus, the modern proposals give consumption tax advocates great hope for moving ahead in the age-old debate between those who advocate consumption taxes and those who advocate income taxes. The theory of individual taxation suggests a new problem for the modern proposals. As I explain below, the modern proposals have a feature that will move the system away from individual taxation. Regardless of other characteristics of the proposals, this feature alone casts serious doubt on the proposals' ability to tax individuals for the value of what they have consumed. The problem stems from the immediate deduction of all capital expenditures. This feature creates effects that will interfere with taxing citizens for the value of what they consume. The problem holds true under varying tax incidence assumptions. In addition, the problem is not shared by other forms of consumption taxes.

Deviating from individual taxation is problematic given that most of the theories offered in support of consumption taxes are grounded in individual taxation. In light of this problem, those who advocate the modern proposals must be willing to rethink or abandon many of the theoretical arguments offered in support.

Part I of the article introduces the concepts of general and individual taxation. Part II explores the types of arguments that dominate tax policy discourse on the whole, not just consumption tax theory. The section then categorizes these arguments in terms of their roots in consequentialist and nonconsequentialist philosophies. The section concludes that modern tax policy arguments fall within the categories of welfarism, weighted welfarism, and nonconsequentialism.

Part III develops a hypothetical tax on sleep to explore which types of tax policy arguments would be consistent with a tax system that does not capture individual taxation. The section concludes that nonconsequentialist theories (theories that evaluate a tax system based on how it conforms to moral norms) depend on individual taxation. In addition, many weighted welfarist theories (theories that strive towards maximizing the sum of individual preferences but include weighting or ranking of preferences) also are grounded in individual taxation. Only simplified welfarism, with the sole goal of maximizing overall economic growth, could support a system regardless of how well it captures individual taxation.

Part IV describes the policy arguments in favor of consumption taxes and categorizes the arguments within welfarism, weighted wel- 
farism, and nonconsequentialism. The section concludes that most of the arguments depend on individual taxation. As the tax system deviates from individual taxation, the theories become less satisfying. The only consumption tax theory that has the potential to support a system regardless of how well it captures individual consumption is a simplified welfarist theory in which the sole goal is increased economic growth. Even pure welfarists, however, would have to recalibrate the economic growth effects in light of the distortions described in this article.

Part $\mathrm{V}$ of this article describes the mechanics of consumption taxes in general and the modern proposals in particular. The section demonstrates that the effects of immediate expensing under the proposals will move the system away from individual taxation. The section shows that these effects occur under varying tax incidence assumptions. If the aim of a consumption tax is to tax consumers on the value of what they consume, the modern proposals fall short.

Part VI of the article concludes that although the modern proposals offer tantalizing claims of resolving past debates, the theory of individual taxation suggests new problems. In particular, consumption tax advocates who favor the modern proposals must be willing to abandon or rethink many of the theoretical justifications offered in support of consumption taxes and acknowledge that only the promise of economic growth can potentially justify the proposals. Finally, the section notes that this article does not try to resolve the classic debates concerning the equity, simplicity, and economic effects of taxing consumption versus income. Rather, the article suggests an additional benchmark for evaluating tax proposals in comparison to their theoretical justifications.

Part VII describes how the concepts of general and individual taxation could be applied to future analyses of other tax systems. As a general matter, the theories presented in this article highlight the contrast between the individualist arguments we make for a particular tax base and our all too frequent blindness to the effects of a tax regime on any individual person. Although the article applies these theories to particular consumption tax proposals, the theories can be applied to other tax systems and to tax policy more broadly. In the end, it is possible that so much of tax theory depends on individual taxation and so little individual taxation occurs that it is worth rethinking our approach to tax policy on the whole. This section offers a few initial thoughts on alternative approaches. 


\section{GENERAL AND INDIVIDUAL TAXATION}

This article introduces the concepts of general and individual taxation. General taxation occurs when a tax system captures the tax base throughout society as a whole and the tax burden falls on those engaged in the taxed activity. Individual taxation occurs when a tax system matches a person's tax bill to that person's share of the tax base. ${ }^{6}$ In other words, with individual taxation, the amount of tax a citizen pays, compared to what other citizens pay, would reflect the value of what that citizen has consumed, compared to the value of what other citizens have consumed. As described in the introduction, general and individual taxation can be explained in the following manner. Suppose we decide to levy a tax of $30 \%$ on all goods consumed during the year. The taxing authorities could add up the value of all of the goods consumed during the year, divide that by the number of goods consumed, and charge each buyer a standard amount of tax on each purchase. With a standard consumption tax of $\$ 100$, for example, consumers would pay $\$ 100$ on the purchase of a tricycle and $\$ 100$ on the purchase of a Mercedes. Such a system would tax the activity of consumption and succeed in collecting the appropriate percentage of the nation's consumption from consumers. It would not, however, tax individuals for the value of what they have consumed.

A system of general taxation is not the same as simply adding up all of the revenue that would be collected by taxing a particular activity, for example, and then collecting that amount some other way. If the government intends to tax a particular activity, the burden of the tax must fall on those involved in the activity. The burden need not be distributed equally, fairly, or in proportion to the value of an individual's participation in the taxed activity. In the end, however, the burden of the tax must fall on those involved in the activity that constitutes the tax base. Without this requirement, it makes no sense to talk about a tax base.

6 In discussing general and individual taxation, I will use the terms tax base to mean what the government intends to tax; tax theory to mean why the government intends to tax the base; and tax mechanism to mean how the government intends to get there. The mechanism need not be direct. For example, suppose the government wishes to impose a tax on cigarette users on the theory that higher prices will discourage cigarette use. The government could impose a tax on cigarette firms with the assumption that firms will pass the tax on to cigarette users in the form of higher prices. If the assumption is correct, the government could reach the tax base of cigarette use without directly taxing cigarette users. Firms, however, will not always pass tax costs on to consumers. 
Suppose, for example, that Bill Gates decides Theodore Kaczynski was right-technology will lead to society's downfall. Gates moves to a cabin in Montana and lives off a backyard vegetable garden, leaving his money in a large bank vault in Seattle. Someone in Washington has the bright idea that if Bill Gates doesn't care about his wealth, we might as well use it to cover everyone's taxes. The government therefore introduces a national sales tax with the following mechanism: Every time someone in America buys something, Uncle Bill pays the tax.

Is this a system of general taxation? After all, the government collects revenue that totals the appropriate percentage of the nation's consumption. Every time consumption increases, tax revenues increase as well. The burden of the tax, however, does not fall on anyone involved in the activity that constitutes the tax base. The tax base is the purchase of goods. Bill Gates is not involved in the purchases of goods at all, and there is no way that Bill Gates can pass the burden of the tax on to those involved in purchasing goods. Given that the tax burden does not fall in any way on those involved in the activity that constitutes the base, the system is not one of general taxation. $^{7}$

Although this article discusses general and individual taxation in the context of consumption taxes, the concepts could be applied to other tax bases as well. For example, Warren discusses a hypothetical agrarian society in which all citizens work in a collective cornfield using their own nondepreciating tools. ${ }^{8}$ The government raises revenue by taking a portion of the crops from the fields before the crops have been distributed to the citizen-producers. For my purposes, I will assume that each citizen receives the amount of corn that can be attributed to that citizen's tools and labor. Warren points out that the government in the hypothetical taxes production. ${ }^{9}$

7 In determining whether the tax burden properly relates to the tax base, it is important to recognize that different tax systems may overlap. For example, an income-type value-added tax and a consumption-type value-added tax differ only in their treatment of capital purchases. See infra note 108. Given that income taxes and consumption taxes overlap substantially, one would expect some correlation between tax burdens under each type of tax. One should not conclude, however, that a consumption tax fails to relate to the base of consumption simply because there is also some relationship between the burden of the tax and income levels. Such a correlation may simply reflect areas of overlap between the two systems.

${ }^{8}$ See Alvin Warren, Would a Consumption Tax Be Fairer Than an Income Tax?, 89 YALE L.J. 1081, 1085 (1980) (criticizing consumption taxes).

${ }^{9}$ See id. at 1086. Warren uses the hypothetical to illustrate the benefits of a Haig-Simons definition of income rather than a definition of income based on society's product. As Warren explains: 
Warren's agrarian society, however, also illustrates general and individual taxation. The tax base is production. The system is one of general taxation because the tax captures the full amount of production that occurs throughout society. In addition, the burden falls on those engaged in the activity of production, who will receive less of the crop after the tax is withheld. The system, however, is not necessarily one of individual taxation. The analysis depends on how the citizens divide the burdens of the tax.

Suppose that under the rules of the agrarian society, each citizen receives a share of the crop based on the value of how much that person produces, and the share is reduced by the appropriate percentage of the tax. ${ }^{10}$ For example, the citizen who has produced $50 \%$ of the value of the crop will pay $50 \%$ of the tax. In that case, each citizen's tax would match that citizen's share of the tax base. The agrarian society would have a system of both general and individual taxation.

One could imagine other tax systems for the agrarian society that would not lead to individual taxation. ${ }^{11}$ For example, suppose that the society distributes the burden of the tax in the following manner: Older workers pay a higher percentage of the tax on the theory that younger workers must feed children and cannot spare as much grain for the government's needs. Under that system, production taxes for citizens would not reflect the value of their production. An older worker, for example, might produce very little but end up paying a large amount of production tax. Thus, the system would not result in individual taxation. The system would result in general taxation, however, because the taxing authority captures the full amount of the base, which is production, and the burden falls on those engaged in the activity of the tax base.

To satisfy individual taxation, a system need not match tax bills and shares of the tax base with absolute precision. No tax system is perfect. For example, a system may fail in a variety of ways to fully

[The tax] is neither a consumption tax (the corn might not all be consumed), nor a wealth tax (some workers may have stores of corn from prior periods), nor a wage tax (it reduced the return to capital, i.e., tools, as well as labor). It is, rather, a tax levied on social output or production for the period.

Id. Although the hypothetical tax system captures all of the society's production, Warren points out that the tax would be an imperfect measurement of income in the society because it fails to capture unexpected returns such as windfalls. Id.

10 Each citizen's production could be measured either by how many hours the individual works or the value of the individual's tools, although this would not account for differences in work effort or talent.

11 This could result directly by assigning citizens the burden of the tax or indirectly through distribution of the benefits of the crop. 
tax all of the activity that constitutes the base. Such deviations may be too insignificant to affect the overall tax burdens of individual taxpayers. Even if the failures are more substantial, the resulting deviations could balance each other out such that tax burdens still correlate reasonably with each taxpayer's share of the base. In those circumstances, the system would still result in individual taxation.

In other circumstances, the system could fail to create individual taxation but still create general taxation. For example, rather than giving up tax revenue, the system may shift tax burdens among those who participate in the activity of the base. As a result, some participants in the activity of the base would pay more than their share and other participants would pay less. Such deviations would move the system towards general taxation, even though it fails to create individual taxation.

In sum, general taxation occurs when a tax system captures the tax base throughout society as a whole and the burden falls on those engaged in the activity of the base. Individual taxation occurs when a tax system matches a person's tax bill to that person's share of the tax base. $^{12}$

12 The theory of general and individual taxation is not the same as shifting and incidence theory, although they overlap at times. To describe the overlap and the distinctions, I will use the definition of shifting and incidence offered by Krzyzaniak and Musgrave in their classic work:

The concepts of "shifting" and "incidence" are not easily defined and mean different things to different people. For the immediate purposes of this chapter, we need only to say that "shifting" of the corporation tax relates to the recovery of the burden which the tax imposes on the taxpayer, the "burden" being the difference in his position as it is with the tax and as it would have been without the tax. The difference may be measured in terms of various "indicators," such as absolute profits, rates of return, or share in national income. The degree to which the potential burden (i.e., the burden which would result in the absence of any adjustment on the taxpayer's part) is avoided or recovered, indicates the "degree of shifting."

Marian Krzyzaniak \& Richard A. Musgrave, The Shifting of the CORPORATION INCOME TAX 8-9 (1963).

On the simplest level, shifting and incidence theory analyzes whether the person who hands over the money for the tax actually bears the burden of the tax. The government may intend for tax shifting to occur. As described above, for example, taxing authorities could levy a tax on firms with the intent that the firms pass the tax on to consumers in the form of higher prices. On a broader level, shifting and incidence theory identifies the systemic effects that may occur when individuals substitute away from taxed activities. It then identifies which citizens will feel the impact of these systemic shifts.

In contrast, the theory of general and individual taxation asks the following: Regardless of the mechanism for paying a tax and after all shifting has occurred, 


\section{THE PHILOSOPHICAL ROOTS OF MODERN TAX THEORY}

Does it matter if a tax system deviates from individual taxation? The answer depends on the underlying theories advanced in support of the tax system. If the theories do not depend on individual taxation, the deviations are irrelevant. If the underlying theories depend on individual taxation, however, the more the system deviates from individual taxation, the less the system is capable of satisfying its foundational logic. The section below examines the types of arguments that dominate the tax policy discourse. Some of the arguments can only support a system of individual taxation. Others have the potential to apply more broadly.

Modern tax policy theories contain echoes of more general works of moral philosophy. In particular, there are strains of either consequentialist analysis, nonconsequentialist analysis, or, in some cases, both.

As a general matter, consequentialism holds that one should evaluate actions based on the state of affairs that would result. ${ }^{13}$ In contrast, nonconsequentialist theories hold that actions may be right or wrong independent of the resulting consequences. ${ }^{14}$

what does the government capture? In particular, does the government succeed in either 1) taxing the activity that has occurred throughout society and distributing the tax burden in some fashion among those engaged in the activity that constitutes the tax base or 2) matching each person's tax burden to that person's share of the tax base?

13 See UtILITARIANISM AND BEYOND 3-4 (Amartya Sen \& Bernard Williams eds., 1982); see also SAMUEL Scheffler, THE REJECTION OF CONSEQUENTIALISM 1 (1982). See infra Part II for a brief overview of the relevant theories of moral philosophy. For more extensive discussions of the theories described here, see RichaRd B. BRANDT, A THEORY OF THE GOOD AND THE Right (1979); JAMES M. Buchanan, The Limits of Liberty (1975); William K. Frankena, Ethics (2nd ed. 1973); R.M. Hare, Moral Thinking (1981); Barbara Herman, The Practice of MORAL JudgMent (1993); DAVId LyONS, ForMS AND LIMITS OF UTILITARIANISM (1965); RoBERT NOZICK, ANARCHY, STATE, AND UTOPIA (1974); SCHEFFleR, supra; Amartya Sen, Equality of What?, in THE TANNER LECTURES ON Human Values 195-220 (Sterling M. McMurrin ed., 1980); The QuALITY OF LifE (Martha C. Nussbaum \& Amartya Sen eds., 1993); UTILITARIANISM AND BEYOND, supra.

Tax policy theories tend to reflect the branch of moral philosophy that tries to establish normative theories to determine whether an action is good or right. See FRANKENA, supra at 4-5 (explaining the difference between works of moral philosophy that provide normative judgments of what is right or good, those that describe history or human nature and those that present "meta-ethical" questions such as whether there is a "right" or a "good"). Tax policy adapts these theories to the peculiar questions of how and if a society should try to apportion the economic benefits and burdens of its activities.

14 See SCHEFFLER, supra note 13, at 4-5. 
The simplest level of consequentialist analysis asks. whether an action would produce a balance of good over bad effects. An action that produces bad effects, even tremendously bad effects, may be proper as long as the total amount of good effects outweighs the total amount of bad effects. ${ }^{15}$

Consequentialism can be further refined by adding the concept of maximization. Maximization requires evaluating an action based on a comparison to all other possible courses of action. In other words, an action is proper if it would lead to at least as great a balance of good over evil as any other option, including inaction. Scholars tend to use the term "consequentialism" to mean the refined form of consequentialism, which strives towards maximizing the good. ${ }^{16} \mathrm{I}$ will do the same for the remainder of this article.

Although consequentialism dictates that actions should be chosen on the basis of whether they maximize the good, consequentialism does not specify whose good should be maximized. Should individuals try to maximize their own good, or should an individual try to produce the greatest good for all? Ethical egoism holds that individuals should try to maximize their own good. ${ }^{17}$ Ethical universalism, more commonly known as utilitarianism, holds that one should try to maximize the good for the community of citizens as a whole. ${ }^{18}$

15 One could imagine a further simplification of consequentialism that would not involve balancing. For example, one could hold that any bad effects, no matter how small, would disqualify a proposed action. Such a theory would be consequentialist in that actions would be evaluated based on the resulting state of affairs, but it would not involve balancing.

16 Frankena adopts this type of refined consequentialism in his work on moral philosophy. In Frankena's formulation, moral philosophies fall within two general categories: teleological and deontological. See FRANKENA, supra note 13, at 14. Teleological theories hold that an act is right if it will "produce at least as great a balance of good over evil as any available alternative." See id. Deontological theories hold that features of the act itself are important regardless of the consequences of the act. See id. at 15. Thus, Frankena's teleology is the refined consequentialism described above in which one tries to maximize good effects after summing up all of the effects. Frankena's deontology then mirrors nonconsequentialism, and the term deontology is often substituted for nonconsequentialism in contemporary philosophy. See, e.g., SCHEFFLER, supra note 13, at 2-3 (citing deontological views as the contrast to consequentialist views and describing deontological views as denying that there is any impartial principle for ranking overall states of affairs from best to worst such that it is always permissible to produce the best available state of affairs). The teleological/deontological formulation is used throughout contemporary literature.

17 See FRANKENA, supra note 13, at 15.

18 See id. at 15-16. Some scholars would include animals as members of the community. See Jeremy Bentham, An InTRoduction to The Principles of MORALS AND LEGISLATION 310-11 n.1 (1948) (arguing for the inclusion of ani- 
Utilitarianism, and its vision of finding the greatest possible good for everyone in the aggregate, infuses much of modern tax policy discourse. ${ }^{19}$

Although consequentialism dictates that one should maximize the good, and utilitarianism adds that one should maximize the universal good, neither one defines what is good. ${ }^{20}$ In other words, both theories tell us to choose actions based on the state of affairs that will result, but neither theory indicates which state of affairs to prefer. ${ }^{21}$

Much of modern tax policy literature, as well as Law and Economics literature in general, judges the desirability of a state of affairs on the basis of people's well-being in it. This approach, known as welfarism, evaluates a particular course of action by measuring the well-being that would result for each person and by adding those amounts together. ${ }^{22}$ Given the difficulty of measuring well-being, modern scholars adopt the convention of measuring the satisfaction of individual preferences. ${ }^{23}$ We measure the satisfaction of prefer-

mals in the calculation of societal utility and noting that "a full-grown horse or dog is beyond comparison a more rational, as well as a more conversable animal, than an infant of a day, or a week, or even a month old").

Scholars distill utilitarianism further into categories of act and rule utilitarianism. Act utilitarianism holds that one should perform acts when the effects would be at least as good as any alternative. See LyONS, supra note 13, at 9 (describing act utilitarianism). In contrast, rule utilitarianism proceeds by asking whether the act conforms to general rules that would promote the greatest general good for everyone. See FRANKENA, supra note 13, at 39; see also SCHEFFLER, supra note 13 , at 2 (referring to "rule" and "act" theories in describing consequentialism); LYONS, supra note 13, at 9-16 (exploring the similarities of act and rule utilitarianism and the limits of both).

19 See infra note 59 and accompanying text.

20 See FranKENA, supra note 13, at 16 (noting that some utilitarians adopt a hedonistic view of the good as pleasure over pain while some adopt an ideal vision of the good but that all utilitarians must accept some theory of value); see also SCHEFFLER, supra note 13, at 3 n.4 (discussing hedonistic and nonhedonistic variants of utilitarianism).

21 One could think of refined consequentialism, however, as providing at least some information about the preferred state of affairs. At the very least, refined consequentialism tells us that the preferred state of affairs is one in which we maximize the good after summing up all of the effects. As described below, the notions of summation and maximization have embedded value judgments. See infra notes 25-28 and accompanying text.

22 See Daniel N. Shaviro, Inequality, Wealth and Endowment, 53 TAX L. REV. 397, 413 (2000); see also Amartya Sen, Utilitarianism and Welfarism, 76 J. PHIL. 463,468 (1979) (With welfarism, "[t]he judgment of the relative goodness of alternative states of affairs must be based exclusively on, and taken as an increasing function of, the respective collections of individual utilities in these states.").

${ }^{23}$ See Shaviro, supra note 22, at 401. Some scholars argue that well-being should be measured using objective criteria, that is, criteria independent of a per- 
ences by measuring one's economic power, that is, one's ability to satisfy one's preferences through the market place. Wealth maximization cannot offer a perfect measurement of well-being. Rather, it is a strategic concession to our inability to measure individual values. In sum, modern welfarism strives to maximize total welfare, with total welfare defined as the summation of each person's ability to satisfy individual preferences. Welfarism then evaluates the ability to satisfy preferences by measuring economic attributes such as income, wealth, or purchasing power. ${ }^{24}$ The summation of each individual's economic power also can be expressed in terms of the nation's total economic power as measured by factors such as gross domestic product.

Consequentialism strives towards maximization of the good, utilitarianism adds that the good should be the universal good, and welfarism defines the good as the summation of the satisfaction of individual preferences. None of the concepts, however, specifies any particular principles of justice as essential or important. This does not mean that adherents to these theories deny the importance of principles of justice such as individual rights, liberty, or equality. A utilitarian or a welfarist could argue that scrupulous respect for individual rights and liberties, for example, is important for the maximization of preferences for everyone. ${ }^{25}$

Although the theories do not mandate one particular good over another, there are value judgments embedded in welfarism and utilitarianism. The theories in their purest form are egalitarian insofar as they hold that the preferences for each individual should count and all types of preferences are equally valid. ${ }^{26}$ Although the term "egalitarian" evokes an image of fairness, counting each person's prefer-

son's tastes and interests. See, e.g., T.M. Scanlon, Preference and Urgency, 72 J. PHIL. 655, 658, 663-64 (1975). In the absence of objective criteria, society could be "held up" by those who have unusually expensive tastes or who attach inordinate importance to some relatively minor concern. Id. at 663.

24 See, e.g., J.A. Mirrlees, The Economic Uses of Utilitarianism, in UTILITARIANISM AND BEYOND, supra note 13, at 63 (using a utilitarian model in which each individual's utility is a numerical function of net income and the quantity of labor supplied).

${ }^{25}$ See JOHN RAWLS, A THEORY OF JUSTICE 26 (1971) (describing utilitarianism). But see Liam Murphy, Liberty, Equality, Well-being: Rakowski on Wealth Transfer Taxation, 51 TAX L. REV. 473, 479 (1996) (arguing that classical utilitarianism is nonegalitarian because it pays no attention to distribution of resources among people).

26 See R.M. Hare, Ethical Theory and Utilitarianism, in UTILITARIANISM AND BEYOND, supra note 13, at 26. But see Elizabeth S. Anderson, What is the Point of Equality?, 109 ETHICS 287, 288 (1999) (exploring different visions of egalitarianism and arguing that egalitarianism has distinctly political aims). 
ences can lead to uncomfortable results. For example, welfarism has been criticized on the ground that it attaches the same weight to a person's enjoyment of food and shelter as to a person's enjoyment from torturing someone else. ${ }^{27}$ The concepts also have a particular focus on the individual. They measure the good by measuring the impact on individuals. In contrast, one could conceivably develop a concept that measures the good by focusing on other measures such as technological advancement of society or longevity of the species. ${ }^{28}$

Maximization and its tolerance of bad effects can produce uncomfortable results, particularly in extreme circumstances. For example, consider the following scenario: In the early twentieth century, doctors believed that stuttering arose from organic causes. One researcher theorized that stuttering had an environmental cause, arising when adults make young children anxious over normal errors of speech development. The researcher, Dr. Wendell Johnson, tested his theory on young children in a state orphanage. He took children with normal speech development, induced a sense of anxiety and self-consciousness about speaking, and induced stuttering. With confirmation of his theory, Johnson went on to develop methods of treating and preventing stuttering that would benefit children throughout the world. ${ }^{29}$

27 See Sen, supra note 22 , at 476 . Utilitarianism does measure the strength of preferences, and stronger preferences may be entitled to greater weight, but this does not always resolve the most disconcerting results. See, e.g., Howard F. Chang, A Liberal Theory of Social Welfare: Fairness, Utility, and the Pareto Principle, 110 YALE L.J. 173, 180-81 (2000) (describing utilitarianism and discussing a preference weighting hypothetical); RONALD DwORKIN, TAKING RIGHTS SERIOUSLY 234 (1977) (describing and criticizing utilitarianism). For example, Hare tries to resolve difficult issues concerning sadistic preferences by arguing that the suffering of the victim is more intense than the pleasure of the sadist. See Hare, supra note 26, at 30 . Suppose, however, that a mob of racists faces a single minority victim. At some point it becomes difficult to argue that the sum of all pleasure of the mob is outweighed by the pain of the single victim. Although one could count the indirect pain experienced by other minority members, one would then have to count the vicarious pleasure of other racists as well.

28 By longevity of the species, I mean how long human beings exist before extinction. I do not mean to imply life expectancy, a measurement that could lead back to focusing on the individual and aggregating the results.

29 The facts described here are as alleged in recent press reports. See Jim Dyer, Ethics and Orphans: An Experiment Leaves a Lifetime of Anguish, SAN JOSE MERCURY NEWS, June 11, 2001, at A1, A8. I assume, for the purposes of the hypothetical, that the facts are correct. The press reports also raise the possibility that stuttering arises from a combination of genetic and environmental causes. If Johnson's theories were only partially correct, then the positive effects of his work may not have been as strong as claimed. The utilitarian value of his work, therefore, would be less clear. 
Suppose, for the sake of the hypothetical, that the experiment clearly benefited thousands of children. An extreme utilitarian form of consequentialism could easily conclude that performing the experiment was proper or "right." Stuttering causes bad effects for those who suffer from it. It interferes with education, stigmatizes the stutterer, and can lead to social isolation. ${ }^{30}$ The experiment brought about a state of affairs in which thousands of children were spared from the terrible effects of stuttering. On the other side of the equation, six normal speaking children were induced to become lifelong stutterers and suffer the ill effects. ${ }^{31}$ From a balance perspective, in which each person's pain counts equally, the experiment moved from a state of affairs in which thousands felt the pain of stuttering to a state of affairs in which only six suffered. ${ }^{32}$

Today's medical ethics, however, follow a more nonconsequentialist approach and would be unlikely to allow an experiment that would intentionally harm a healthy subject regardless of how many

30 See id.

31 It is curious that Johnson's theories and treatments never benefited the six who were induced to stutter. The researchers may not have made a sustained effort to reverse the effects of their experiment, an effort that would have required revealing the nature of the experiment to the teachers and students at the orphanage. See id. Those induced to stutter also may not have had the resources to explore all treatment options. These issues suggest that a better course of action would have been to offer treatment to the six who were induced to stutter. This does not answer the question, however, of whether it was right to induce stuttering in the first place, although it might suggest, from a utilitarian viewpoint, that the harm could have been reduced.

Finally, it may be that Johnson's approaches, while revolutionary, could not cure all stuttering or completely reverse the effects of stuttering. See id. For the purposes of the hypothetical, however, I assume that six were injured while many were spared the identical injury.

32 To reach this conclusion, one must assume that no other alternatives existed for confirming his theories in a way that would lead to alleviation of stuttering for the thousands of children. At the very least, one must assume that without the experiments, Johnson would not have developed his methods for a number of years, a delay that would have caused a significant number of children to experience the secondary effects of stuttering in an irreversible manner.

The stuttering hypothetical avoids the problem of comparing different types of utility and disutility. Consider the question of whether a sadist should be allowed to torture someone. One could decide against this action in a manner that is consistent with utilitarianism by arguing that the pleasure a sadist experiences is not as great as the pain felt by the victim. See Hare, supra note 13, at 30 (The suffering of the victim is normally more intense than the pleasure of the sadist.). Thus, the balance of good over bad effects would not allow the action. In the stuttering hypothetical, however, the benefits and harms are roughly equal. Some children are inflicted with the lifelong harms of stuttering while others are relieved of this burden. 
others would be helped. ${ }^{33}$ In this case, modern medical ethics would be following a nonconsequentialist view that acts must conform to moral norms, regardless of their good or bad effects. ${ }^{34}$

Utilitarianism and welfarism create other problems, particularly for tax theorists. The notion of maximizing the sum of individual preferences suggests that all preferences are the same. Thus, a wealthy person's desire for luxury goods would weigh equally with a poor person's desire to avoid starvation. Welfarism attempts to resolve this problem by the theory of declining marginal utility, which assumes that certain desires will be stronger than others. When comparing a wealthy person who has one hundred apples to a poor person who has one, the welfarist assumes that an additional apple is worth more to the poor person than to the wealthy one. After all, there is only so much that the wealthy person can eat. On the other side of the equation, the drive to avoid starvation must be quite strong. Thus, although we may not be able to specify the precise mathematical function for declining marginal utility, we do assume that utility declines as people have more. This allows us to conclude that the welfare of worse off individuals should, to some extent, count for more in the social welfare calculus. ${ }^{35}$

Shaviro refers to this approach as "weighted welfarism."36 I will use the term weighted welfarism to include all welfare-based theories that involve ranking of preferences or an assumption that certain preferences have greater weight.

Declining marginal utility allows theorists to assign a higher value to certain preferences on the assumption that those preferences will be held more strongly. A more ambitious approach, however, holds that not all preferences should be counted. ${ }^{37}$ For example, Goodin proposes that we can ignore some of a person's preferences,

33 See Dyer, supra note 29. The stuttering experiment also raises issues of consent. The children were not told of the possible harm of participating in the study, nor were they told later that their stuttering had developed because of the experiment. The press report suggests that either officials at the orphanage or from the state consented. The question then becomes the extent to which parents or adults can consent on behalf of children to something that could directly harm the children while providing them no benefit. Although the consent issues are interesting, a nonconsequentialist could conclude that harmful experiments on healthy subjects should not be permitted even if those subjects agree and have the capacity to agree.

34 See LyONS, supra note 13, at vii.

35 See, e.g., Shaviro, supra note 22, at 413.

36 See id.

37 For a thorough description of modern philosophical theories that take a utilitarian or welfarist approach but would limit the types of preferences, see Chang, supra note 27, at 179-208. 
particularly if our approach to sorting a person's preferences mirrors the way in which individuals would sort their own preferences. ${ }^{38}$ Similarly, Harsanyi argues that in defining the concept of social utility, we must exclude antisocial preferences such as sadism, envy, resentment, and malice. ${ }^{39}$ Others argue that we should only count preferences that are rational and fully informed. ${ }^{40}$

Dworkin, in criticizing utilitarianism, argues that to make utilitarianism internally consistent, one could only include preferences for one's own enjoyment of goods, not those related to goods and opportunities for others. ${ }^{41}$ Dworkin refers to these two categories as personal and external preferences. He ultimately rejects this modification of utilitarianism on the grounds that personal and external preferences may be inextricably tied together. ${ }^{42}$

38 See Robert E. Goodin, Laundering Preferences, in Foundations of Social CHOICE THEORY 81 (Jon Elster \& Aanund Hyllands eds., 1986).

39 See John C. Harsanyi, Morality and the Theory of Rational Behavior, in UTILITARIANISM AND BEYOND, supra note 13, at 56.

40 For example, in Hare's view, we should only count those preferences that individuals would hold if they were fully informed and unconfused. See Introduction to UTILITARIANISM AND BEYOND, supra note 13, at 9. (describing Hare, supra note 26). Similarly, Harsanyi argues that in addition to excluding antisocial preferences in defining social utility, preferences should only be counted if they are what people would choose if they had all the relevant information and reasoned with the greatest possible care in a state of mind conducive to rational thought. See Harsanyi, supra note 39 , at 56.

One could view Rawls' veil of ignorance as a variation on this theme. Rawls' theory of justice, which he contrasts with both utilitarianism and nonconsequentialism, includes the notion that one should ask what people would prefer if they had no idea what attributes they would have in life. See RAWLS, supra note 25, at 13642 .

${ }^{41}$ DwORKIN, supra note 27, at 234. Dworkin argues that counting external preferences would corrupt the egalitarian nature of utilitarianism. If we count external preferences, the chance that anyone's preferences would succeed depends not only on the demands that others make on scarce resources but also on the respect or affection that others have for the person and the person's way of life. This would induce a form of double counting in which a popular person's preferences count twice: once when the person desires something and once when others desire it for him. See id. at 235. But see Chang, supra note 27, at 184 (adopting a modified version of Dworkin's distinction between personal and external preferences but criticizing the notion that counting external preferences constitutes double counting).

For example, Dworkin considers the case of citizens who want to limit the public display of pornography because they do not wish to encounter pornographic imagery. Dworkin notes that such a preference could be legitimate because it emphasizes not how others should lead their lives but the character of the sexual experience that the censors want for themselves. See RoNALD DwORKIN, A MATTER OF PRINCIPLE 364-65 (1985).

42 See DWORKIN, supra note 27, at 236. This linkage of personal and external 
While some scholars modify welfarism by eliminating certain preferences in accordance with moral norms, others argue that one can establish a hierarchy of principles in which both maximization and moral norms play a role. For example, Chang, who applauds the notion of ignoring some types of preferences, ${ }^{43}$ argues that we can retain maximization principles while using fairness principles to determine how to trade off the welfare of some against the welfare of others. ${ }^{44}$ In other words, the point of maximization can be reached in varying ways, and we should use fairness principles to choose among the different paths. Maximization becomes the first norm, with justice a subsidiary norm. ${ }^{45}$

Although these modifications to welfarism allow ranking or choosing among preferences, they remain at least nominally within the confines of a utilitarian structure. In contrast to the utilitarians and weighted utilitarians, however, are the nonconsequentialist theories. These are sometimes called "rights-based" 46 theories because they frequently involve protection of individual rights such as liberty. ${ }^{47}$

preferences reminds me of the cartoon in which an employee says to his boss, "O.K.., if you can't see your way to giving me a pay raise, how about giving Parkerson a pay cut?" B. Smallen, NEW YORKER, May 21, 2001, at 91. In other words, sometimes what we want for ourselves is intimately connected with what we want for others. The employee doesn't want more money; he wants more money in relation to his colleagues.

43 See Chang, supra note 27, at 185.

44 See id. at 178-79. Chang describes his theory as consequentialist, because policies are to be chosen based on the resulting state of affairs, but not utilitarian or welfarist, because he considers the sources rather than just the content of utility. Id. at 195. I include Chang's theory in the category of modified utilitarianism.

45 See id. at 178 (noting that "there is nothing to prevent a pluralistic fairness theory from including the Pareto principle among its principles and giving the Pareto principle priority over other principles").

Alstott offers a description of liberal theory that would fall into a reverse version of this category, with justice as the primary norm and maximization of preferences through the market as a subsidiary norm. She defines liberal theory as acknowledging the advantages of the market in allocating resources to provide goods people want but requiring the market to operate within the confines of just background institutions that mitigate disparities in wealth. See Alstott, supra note 1, at 378.

46 See, e.g., McCaffery, supra note 1, at 290.

47 For example, Nozick contrasts utilitarianism with theories that place nonviolation of rights at their cores. Nozick's rights, however, are individual rights. See NozicK, supra note 13, at 28-9. The choice of the term "rights-based," however, is misleading. Nonconsequentialism simply requires that actions conform to certain types of moral norms, regardless of the consequences. Those norms might or might not relate to individual rights. 
Nonconsequentialist theories hold that actions are right or wrong based on their nature or their conformance to certain norms, regardless of the resulting consequences. The proper nature or norms may follow any type of dictate-justice, individual liberty, autonomy, etc. The heart of this approach is that core values matter independently of consequences.

Nonconsequentialism is not merely utilitarianism with the key rights as the desired state of affairs. In other words, one could conceivably argue the following: If utilitarianism strives towards maximization of the universal good, why can't we just say that the universal good is a moral, nonconsequentialist goal such as the protection of individual rights? If we maximize the protection of individual rights, haven't we satisfied the dictates of both nonconsequentialism and utilitarianism?

The problem with this approach is that nonconsequentialism is inconsistent with maximization. For example, suppose that society had to violate the rights of one individual in order to maximize the total amount of protection of rights in a society. A utilitarian would violate the rights of the one person. In contrast, a nonconsequentialist, for whom rights matter independently of consequences, might not approve. ${ }^{48}$ If the rights of the individual are of core importance, a consequentialist would be reluctant to trade off the rights of one, even if it resulted in preserving the rights of many.

In contemporary tax policy literature, the contrast between consequentialism and nonconsequentialism appears most strikingly in the question of how to approach distributional concerns. Tax policy theorists from a variety of political and philosophical perspectives are troubled by the disparities in society. As Rakowski notes: "[d]isparities in means and opportunity between the poor and the prosperous yawn too wide to be shrugged off as the unpleasant but tolerable by-product of a market economy or individual license, let alone as the sort of cosmic misfortune that lies beyond human remedy." 49

48 Id. at 28-9 (explaining that protection of rights is not merely a "utilitarianism of rights"). Nozick explains further that his vision would not forbid all tradeoffs if those trade-offs are in pursuit of some desirable society that he would choose to inhabit despite the fact that some rights are sometimes violated. Id. at 28 .

The argument works better, however, with the simplest level of consequentialist analysis that does not involve balancing or maximization. See supra note 15 (describing a consequentialist approach in which bad effects, no matter how small, would disqualify an action).

49 Eric Rakowski, Can Wealth Taxes by Justified?, 53 TAX L. REV. 263, 263 (2000). 
Both consequentialists and nonconsequentialists worry about societal distribution and advocate actions that would ease disparities. The two types of theorists, however, see distributional disparities as important for entirely different reasons. Contemporary welfarism, a consequentialist approach, assigns a higher value to the preferences of those who have less, on the theory that these preferences will be held more strongly. ${ }^{50}$ As a result, welfarists see transfers from those who have more to those who have less as potentially maximizing overall welfare. Such transfers would be limited by the extent to which transferring wealth might deter productive members of society from working, thereby reducing total societal welfare. The tax rate should be set to "optimize the value of progressive redistribution that can be accomplished relative to the cost of deterring work effort through the tax." ${ }^{, 51}$ Thus, contemporary welfarists see redistribution as important to the pursuit of maximizing overall welfare.

Nonconsequentialists, however, would see wealth transfers as important for reasons independent of the overall welfare consequences of such transfers. In other words, wealth transfers are important because they conform to moral norms, regardless of whether such transfers would maximize the total welfare in society. For example, a nonconsequentialist might see the question framed as a clash between two sets of moral goals: an individual's right to the fruits of one's labor versus the moral dictates of equality in society. ${ }^{52}$

Different nonconsequentialists may favor wealth transfers according to different moral norms. For example, wealth transfers conform to liberal notions of the right to equality of resources throughout society. Liberal theorists could advocate transfers on this basis. ${ }^{53}$ Other contemporary theorists, however, reject the notion that we should transfer wealth to people merely because they have less wealth than others. ${ }^{54}$ For example, suppose individuals have less because they have chosen to gamble their money away and spend their time hanging out at the beach. Should we still transfer wealth to them? In response to such concerns, a number of scholars argue that distributive rules should be based on the notion that individuals are

50 This conclusion follows the logic of declining marginal utility. See supra text accompanying notes $37-38$.

51 Shaviro, supra note 22, at 413 (describing the optimal tax literature inspired by Mirrlees). See Mirrlees, supra note 24, at 175.

52 See Shaviro, supra note 22, at 417, 419 (describing theorists who view distributive justice from the position that "rights matter independently of consequences" and contrasting these theorists with utilitarians); Murphy, supra note 25, at 475 (describing liberalism).

53 See Murphy, supra note 25, at 475 (describing liberalism).

54 See id. at 481 (describing choice theory). 
entitled to the resources and opportunities that flow from their own effort or choices. ${ }^{55}$ Some scholars refer to this theory as the "choices thesis." 56

Shaviro describes such theorists as "liberal egalitarians" and includes in this category scholars such as John Rawls, Ronald Dworkin, Bruce Ackerman, Eric Rakoswki, Thomas Nagel, Amartya Sen, and Thomas Scanlon. ${ }^{57}$ Although the term liberal egalitarianism is used throughout the literature, there is disagreement over whether a clear category exists, which scholars would fall into such a category, and what commonality of thought can be found among such scholars. ${ }^{58}$

\section{TAX POLICY ARGUMENTS IN GENERAL}

Many tax policy arguments are based on straight welfarism, which strives to maximize the satisfaction of preferences, measured

55 See, e.g., Rakowski, supra note 49, at 283 (advocating this approach); see also Shaviro, supra note 22, at 417 (describing choice theory). Declining marginal utility also does not analyze the source of an individual's lack of wealth, and thus is vulnerable to the same type of criticism. See id. (declining marginal utility ceases to provide clear-cut guidance to distribution policy once one considers taste differences).

See Murphy, supra note 25, at 474; Shaviro, supra note 22, at 417-18. See also Rakowski, supra note 49, at 285 (describing the approach and contrasting it with "choice-independent" theories of justice); Anderson, supra note 26, at 289 (criticizing choice theory and arguing that "in attempting to ensure that people take responsibility for their own choices, [the theory] makes demeaning and intrusive judgments of people's capacities to exercise responsibility, and effectively dictates to them the appropriate uses of their freedom").

57 See Shaviro, supra note 22, at 417. The term "liberal egalitarian" connotes a combination of traditional liberal theories along with notions of equality. See Murphy, supra note 25, at 475-76. John Rawls is considered a prominent member of this philosophical approach. See id.; McCaffery, supra note 1, at 291; see also RAwLS, supra note 25 . The definition is of limited value, however, given that liberalism is difficult to define. See Murphy, supra note 25, at 475; Eric Rakowski, Transferring Wealth Liberally, 51 TAX L. REV. 419 (1996) ("Liberalism is a wooly doctrine...."). In addition, as Murphy suggests, core concepts in liberalism and egalitarianism may conflict given liberalism's emphasis on individual autonomy and egalitarianism's focus on equality. See Murphy, supra note 25, at 475-76; see also Alstott, supra note 1, at 377 . (describing liberalism as seeking to give people considerable freedom in pursuing their own vision of the good).

58 See, e.g., Shaviro, supra note 22, at 417 ("'[O]ne might say of liberal egalitarians (even accepting the existence of such a group) that each has a distinct theory, and thus that generalization about their views is dangerous."); Murphy, supra note 25 , at 475 (arguing that liberal egalitarianism should not be characterized by an appeal to the choice thesis); Rakowski, supra note 57, at 427 (criticizing McCaffery's choice of scholars to include as liberal egalitarians); see also McCaffery, supra note 1, at 289-97 (discussing liberal egalitarianism and wealth transfers). 
by economic attributes, throughout society as a whole. Such arguments evaluate a tax proposal by measuring its potential effects on the economic growth of the nation as a whole. ${ }^{59}$ Others adopt a weighted welfarist approach, which considers not only economic growth but also distributional issues based on declining marginal utility. Such approaches do not necessarily create a function to represent declining marginal utility, but they do consider the effects of various tax proposals on different cohorts. A weighted welfarist would look not only at the effects on economic indicators such as gross domestic product and interest rates, but also at shifts in the tax burden from one group to another that would represent redistribution with the implication that increased burdens on lower earners is a "bad effect" of the proposal to be balanced against the gains in growth. ${ }^{60}$. Within this category of weighted welfarists are those who would allow ranking or weighting of preferences, such as Chang, in which maximization principles are primary while other justice principles may play secondary roles. $^{61}$

Still other tax scholars reject welfarist notions entirely and evaluate tax proposals on the basis of moral rights. For example, Rakowski rejects a wealth tax on grounds that such a tax would fail to respect individuals' rights to resources and opportunities in consequence of their choices. ${ }^{62}$ In contrast, Ackerman and Alstott propose a wealth tax, grounding their proposal in notions of a need to create truly free and equal citizenship and specifically rejecting maximization of social welfare. ${ }^{63}$ Although these approaches to wealth taxa-

59 See, e.g., Dale W. Jorgenson, The Economic Impact of Fundamental Tax Reform, in FRONTIERS OF TAX REFORM 181, 181 (Michael J. Boskin ed., 1996); Eric M. Engen \& William G. Gale, The Effects of Fundamental Tax Reform on Saving, in ECONOMIC EFFECTS OF FundAMENTAL TAX REFORM 83, 83 (Henry J. Aaron \& William G. Gale eds., 1996). Auerbach notes that recent tax proposals aim to "increase the growth of the economy and the standard of living," although he measures distributional effects as part of his economic model. Auerbach, supra note 2 , at 29,60 .

60 For example, a number of theorists tweak the tax proposals in various ways and then measure the trade-offs between growth and redistribution towards lowerearners. See, e.g., Auerbach, supra note 2, at 60-1; Altig et al., supra note 1, at 590-91; William G. Gale, Scott Houser \& John Karl Scholz, Distributional Effects of Fundamental Tax Reform, in ECONOMIC EFFECTS OF FundAMENTAL TAX REFORM 281, 281 (Henry Aaron \& William G. Gale eds., 1996).

61 See Chang, supra note 27.

62 See Rakowski, supra note 49, at 283, 374-75.

63 See Bruce ACKerman \& ANNe Alstott, The Stakeholder Society $3-$ 5 (1999). Ackerman and Alstott propose a $2 \%$ wealth tax to finance a one-time grant to young adults. 
tion reach opposite conclusions, both reject welfare effects and operate from a nonconsequentialist vision of core moral rights.

Not all of the philosophical approaches described above could support a tax system regardless of how well it captures individual taxation. The following two sections explore the key tax policy theories and identify whether each theory could support a system that deviates strongly from individual taxation.

\section{A. Applying the Tax Policy Arguments: A Sleep Tax}

As a vehicle for examining the philosophical roots of tax policy discourse, this section describes how nonconsequentialists, welfarists, and weighted welfarists might evaluate a tax on the activity of sleep. The following section then analyzes whether these arguments could support a sleep tax system regardless of how well it captures individual taxation.

Suppose that the government wishes to tax the activity of sleep. How would welfarists, weighted welfarists, and nonconsequentialists view such a tax? First, recall that welfarists evaluate tax proposals by measuring the potential effects on national economic growth. Welfarists might approve of a sleep tax on the grounds that it could discourage nonproductive activity. Hours devoted to sleep cannot possibly be devoted to labor activities, and it is labor activities that translate into national economic growth. Thus, discouraging sleep could encourage the wakeful activities that contribute to economic expansion.

Discouraging sleep does not guarantee that citizens will work more. One could sleep less and simply engage in more leisure activities rather than more labor. ${ }^{64}$ The sleep tax, however, could be combined with a consumption tax so that leisure activities such as reading a book, eating, or surfing at the beach would be taxed as well. Thus, when a citizen's nonproductivity escapes the sleep tax, the government could, at a minimum, tax the book, the food, or the surfboard. ${ }^{65}$

64 One could also be engaged in labor activities during waking hours that escape taxation, such as painting one's own house or caring for one's own children. Such personal labor would at least constitute productive activity, even if it is never taxed or included in a measure of gross domestic product. Thus, the sleep tax's failure to tax such activity at least would be consistent with maximizing productive activity, if not economic growth.

65 To the extent that such a consumption tax is aimed only at nonproductive activities, it may be difficult to limit its reach. For example, one would have to distinguish between pencils purchased for writing love letters and pencils purchased for writing quarterly reports. There is also a potential theoretical overlap between purchases for leisure and purchases for labor. The definition of consump- 
In addition, waking hours at least have the potential to be productive. One could imagine the political campaign that would accompany passage of the sleep tax as elected officials exhort their citizens to sleep less and work more: "A nation asleep is a nation at risk" and "We cannot be a nation asleep at the switch."

Basic utilitarian welfarism would take into account those whose jobs are more physically demanding and therefore require more sleep. Thus, the social welfare function would include factors that compensate for those jobs that require a greater amount of sleep. The sleep tax also would be bounded by the extent to which deterring sleep in the name of production makes workers too tired to work. If we are too successful at discouraging sleep, our workers really will be falling asleep at the switch. This is the type of maximization calculus that fits perfectly within a welfarist approach. Such an approach would be concerned with finding the optimal point to set the tax for deterring any sleep beyond that necessary to fuel productive capabilities and stimulate economic growth.

Weighted welfarists might be concerned about fairness issues inherent in the sleep tax. What about people whose physical makeup

tion, however, views individual consumption in isolation from the production cycle. It suggests that an individual's consumption has no productive element at all. This implication is misleading in two respects. First, production and consumption are part of the same economic cycle. See Michael J. Boskin, A Framework for the Tax Reform Debate, in FrontIERS OF TAX REFORM 10, 18 (Michael J. Boskin ed., 1996) (describing the production cycle). One could certainly export goods in an open economy, but it is hard to imagine an economy that can thrive without significant levels of domestic consumption. Thus, it is misleading to suggest that only the production side of the equation has value for economic expansion. To create economic expansion, businesses must increase their production, but individuals must increase their consumption as well.

Second, it is artificial to suggest that an individual exhausts resources solely for personal reasons and not in any way for the purpose of production. Just as a business uses up bricks and mortar in the pursuit of production, one could argue that a worker uses up food in a similar pursuit. See Alstott, supra note 1, at 378 n.51. Workers will not last very long if they do not eat. Certainly, some of the food will fuel leisure, rather than work. Leisure itself, however, may be a form of fuel to the individual worker. No one could be productive working during every waking hour. The most efficient working level probably involves some balance of work and leisure. Thus, leisure could be considered fuel for the worker as well. It would be difficult to argue that all luxury goods are fuel to the worker. Nevertheless, for some people, the prospect of earning enough to buy luxury goods provides the incentive for work, depending on their personal utility curves and the resources they have acquired through accumulation and inheritance. I do not wish to suggest that all consumption occurs for the purpose of production. Individual consumption, however, cannot be neatly separated from the production cycle. Consumption of goods by human factors of production may be analogous to consumption of goods by machines. 
requires more sleep? Should we discriminate against them on the basis of a natural attribute? What about working parents who are more exhausted at the end of the day? Doesn't parenting contribute to society in a way that should be rewarded, regardless of whether the value of parenting shows up in the gross national product? This, of course, may not be a problem given that working parents may get less sleep than the rest of the population, but we might want to allow a weekend nap allotment.

In evaluating various sleep tax proposals, weighted welfarists might favor those that sort among preferences for sleep. Thus, weighted welfarists might favor plans that tax sleep for leisure but exempt sleep for natural physical attributes, such as excessive sleep needs, or give allowances for sleep related to possible social activities outside of labor such as parenting or charitable work. Such an analysis preserves the overall framework of maximization of social welfare measured by economic growth but includes some weighting and ranking of preferences.

Nonconsequentialists might evaluate the sleep tax on an entirely different basis. Nonconsequentialists would ask how it conforms to basic moral norms, regardless of how well it creates an increase in national work ethic and stimulates economic growth. A liberal egalitarian theorist who believes that people should be entitled to the resources and opportunities that flow from their own efforts or choices might support an excess sleep tax. The government could allow for a sufficient amount of sleep to satisfy physical needs, and this could be tailored to the particular needs of the individual. Any excessive malingering in bed, however, would be taxed on the theory that those who choose productive activities should receive the fruits of their labor while those who do not may be penalized.

Other nonconsequentialists might oppose any sleep taxes on the grounds that such taxation would interfere with the basic right to control personal autonomy. ${ }^{66}$ How can the government dictate the proper amount of sleep? Others might express privacy concerns: The government does not belong in the bedroom measuring our REMs. ${ }^{67}$

In addition, nonconsequentialists might identify other fairness issues such as distributional concerns. As described above, the utilitarian social welfare function would compensate for jobs that are more physically demanding by allocating more hours of sleep to those jobs. Thus, a tax system following these dictates would give incen-

66 This argument is reminiscent of Nozick's view that taxation of earnings from labor is on a par with forced labor. See NozICK, supra note 13, at 169.

67 REMs are rapid eye movements associated with the dreaming phase of sleep. 
tives for more sleep to those who have more physically demanding jobs. ${ }^{68}$ In today's society, men predominantly hold the more physically demanding jobs. Is it fair to promote a societal structure in which men are permitted greater rest than women?

Moreover, given the difficulties of measurement, one could imagine a system that simply allotted more sleep to men in light of their greater potential to handle more physically demanding jobs. We may not be able to measure each person's variation in sleep needs related to their job and thus, for ease of administration, it would be better to draw a bright line and allocate a sleep tax advantage to those who have the greater potential. ${ }^{69}$ Would that be an equitable system?

A utilitarian could argue that the uncomfortable aspects of this hypothetical flow from measurement errors. We are simply unable to measure or recognize the physical and psychic demands of activities such as childbearing, childrearing, and relationship building-all of which require greater rest to promote proficiency.

The discussion above describes how welfarist, weighted welfarist, and nonconsequentialist arguments might be used in support of a proposed tax, such as a sleep tax. The following section explores whether those arguments would be sustainable if the system resulted only in general taxation or otherwise failed to produce individual taxation.

68 This is roughly analogous to the notion in distributive arguments that those who have a greater distribution of wealth are simply the beneficiaries of the fact that their natural talents, or the jobs they are willing to take, are more valuable to society. Thus, society should be unconcerned about their greater wealth attributes, at least up to some point. Arguments in response include 1) differences in compensation may not necessarily correlate with talent or willingness to work but may be a factor of luck or unfair societal advantages; and 2) differences in compensation at times seem strangely mismatched to the notion of who contributes most to society. See, e.g., Rakowski, supra note 49, at 285 (describing differing philosophical treatments of origins of unequal possession of wealth and society's responsibilities); ACKERMAN \& ALSTOTT, supra note 63, at 160-62 (arguing that wealth inequalities are at least partially based on class and unequal opportunities); $c f$. Alstott, supra note 1, at 376-77 (discussing investment returns on Ultra Slim Fast and arguing that "one can and should distinguish between investments that serve the rather narrow, private interests of consumers and producers and competing uses of social resources that arguable would do more to promote the public interest").

69 Such an allocation of tax resources also might prove to be an incentive to men to do more physical work. 


\section{B. Which Tax Policy Arguments Could Support a System Regard- less of How Well it Captures Individual Taxation?}

In a tax system that produces individual sleep taxation, the government would match each individual's sleep tax to that person's actual amount of sleep. Some of the arguments described above would support a system regardless of how well it captures individual taxation. Others would not.

A system that fails to capture individual taxation would not satisfy the demands of nonconsequentialist theories: For example, consider the nonconsequentialist theory described above in favor of an excess sleep tax. The argument is based on the notion of preserving individuals' rights to the resources that flow from their choices. A tax that does a poor job of matching taxpayers' bills to their level of sleep could not satisfy such dictates.

Most nonconsequentialist theories would encounter similar problems. Such theories would choose the tax base, such as sleep, because taxing the activity or attribute conforms to moral norms or standards. A tax system that fails to capture the base could not satisfy such theories. Even a tax system that succeeds in taxing the base across society as a whole is unlikely to satisfy theorists who are concerned about individual moments in which the tax impinges on moral norms. ${ }^{70}$

A system that fails to produce individual taxation would be problematic for basic utilitarian welfarism, however, only in terms of properly calculating the incentive effects of the system. Welfarism evaluates a particular course of action by measuring the well-being that would result for each person and adding those amounts together. $^{71}$ Thus, although welfarists look at the overall results after summation, the results are based on a system's effects on the individual.

For example, to simulate the overall economic effects of a consumption tax, welfarist analysts estimate how individuals will alter their spending and saving patterns if consumption is taxed. If each person's consumption tax does not correlate well with that person's level of consumption, the incentive effects of taxing consumption will not operate fully. Although the system could still result in economic growth, that result would have to occur despite the altered incentives or in response to incentive effects from some other aspect of the way in which the system operates. Thus, in theory, a system

70 See supra text accompanying notes 47-49 (explaining why nonconsequentialism is not merely a utilitarianism of rights).

71 See supra text accompanying note 22. 
could result in overall economic growth despite the system's failure to produce individual taxation. A welfarist evaluation of the system, however, would have to be able to predict and account for the altered incentive patterns of the system's failure to tax individuals on their level of taxed behavior.

In addition to the problems all welfarists would encounter, weighted welfarists would encounter particular difficulties. Weighted welfarists accept the general contours of welfarism, but weight or rank preferences in pursuit of the best resulting state of affairs. If the weighting or ranking relates to an individual's level of sleep, a system that fails to produce individual taxation would be insufficient for a weighted welfarist.

For example, a weighted welfarist might evaluate a sleep tax system based on whether it ensures fair patterns of sleep distribution as a secondary consideration to the maximization of economic growth. For such a theorist, a sleep tax would be good if it promoted economic growth by encouraging work effort but also was designed to ensure a fair distribution of sleep throughout society. A sleep tax that fails to tax individual sleep patterns may be an unsatisfactory vehicle for ensuring fair sleep distribution, unless of course the deviation relates to the system's redistribution of sleep. It would be difficult for a tax system to address sleep distribution issues if the system is not matching sleep levels and tax levels. Even if a system succeeds in capturing the total amount of sleep throughout society, this fact would be of little help in satisfying goals that relate to an individual's level of sleep.

An exception to the point exists when the specific weighted welfarist goal is to create taxation that does not match an individual's tax base. For example, in any progressive system, the government applies a higher tax rate to those who have more of the tax base, rather than matching taxation to a person's share of the base. Given that the system shifts tax among those engaged in the activity of the base, one could argue that the system now creates only general taxation rather than individual taxation. When the weighted welfarist goal is to prevent matching an individual's tax with that person's tax base, the goal could only be satisfied through a system that fails to create individual taxation. Even such a goal could be thwarted, however, if the resulting system creates additional shifting that thwarts the weighted welfarist goal. In addition, although in a progressive tax system, a person's tax does not match that person's share of the tax base, progressive tax systems do establish a formula for relating tax shares and shares of the base. Thus, it may be possible to argue that such systems satisfy an expanded notion of individual taxation on the grounds 
that the systems maintain a constant relationship between tax burdens and shares of the base.

As another example of the difficulties of satisfying weighted welfarist goals without individual taxation, suppose we discover that poor people get less sleep. A weighted welfarist, who is concerned with redistribution of income rather than redistribution of sleep, might approve of a sleep tax on the grounds that the poor will pay less tax. Accomplishing this result, however, depends on the fact that the poor, who get less sleep, will pay less tax. If the system does not match peoples' level of tax to their level of sleep, the result will not occur.

A system of general taxation also could satisfy the demands of a weighted welfarist in other, very limited circumstances. This could occur when the weighted welfarist rankings do not relate to the base itself and reaching the improved state of affairs implied by the rankings does not depend on an individual's share of the base. It would have to be true that by some mechanism unrelated to an individual's amount of sleep, for example, a sleep tax has the coincidental effect of promoting nonsleep goals such as economic growth and redistribution of wealth. In short, one would have to support a sleep tax with theories entirely unrelated to sleep and satisfy the theories with mechanisms unrelated to sleep. At some point, the notion of using sleep as a tax base would have little meaning.

In sum, as a general matter, nonconsequentialist and many weighted welfarist theories would not support a tax system that fails to produce individual taxation. Basic welfarism could, in theory, support such a system, but one would have to ensure that the social welfare function properly predicts and accounts for the system's unusual incentive patterns.

\section{CONSUMPTION TAX THEORY}

The section above describes the key arguments in the tax policy discourse in general. The following section sets forth the arguments specifically in favor of consumption taxes. Part A describes the arguments. Part B categorizes the arguments within welfarism, weighted welfarism, and nonconsequentialism. Part $\mathrm{C}$ analyzes which of the arguments could support a system regardless of how well it captures individual consumption.

\section{A. Consumption Tax Arguments}

According to advocates of consumption taxation, one should think of society's resources as existing in a common pool. Those 
who remove resources from the pool for personal use should be taxed. Those who contribute to the pool should not. Early stirrings of the idea can be found in Hobbes' work in the seventeenth century, in which he suggests that an individual should be taxed based on the amount of society's resources that individual uses. ${ }^{72}$

Other scholars, such as John Stuart Mill, expand the notion by considering not only what an individual takes from society's resources but also what an individual contributes. ${ }^{73}$ In this approach,

\section{Hobbes writes}

the Equality of [taxation], consisteth rather in the Equality of that which is consumed, than of the riches of the persons that consume the same. For what reason is there, that he which laboureth much, and sparing the fruits of his labour, consumeth little, should be more charged, then he that living idlely, getteth little, and spendeth all he gets; seeing the one hath no more protection from the Common-wealth, then the other? But when the [taxes], are layd upon those things which men consume, every man payeth equally for what he useth; Nor is the Common-wealth defrauded by the luxurious waste of private men.

ThOMAS Hobbes, LeVIATHAN, OR THE MATTER, Forme, \& POWER OF A COMMONWeAlTH ECCLESIASTICALL AND CIVILL 267 (1651), reprinted in HobBes's LeVIATHAN, Oxford University Press (1909). Hobbes would treat the two citizens equally because they spend the same amount. His goal is simply that "every man payeth equally for what he useth."

As with many enduring quotations, however, there are numerous concepts woven into Hobbes' words. For example, the quote is embedded in a section in which Hobbes argues that all men receive the benefit of personal security from the sovereign and that such a benefit is of equal value to each man. In addition, the quote itself concludes with a phrase suggesting that the two individuals are equal because of the equal protection that they receive: "seeing the one hath no more protection from the commonwealth than the other." This has lead some scholars to suggest that, rather than a consumption tax, Hobbes might have favored benefits taxation, in which each individual pays for whatever benefits the government provides, or a simple lump-sum tax paid by each person. See McCaffery, supra note 1, at 338 n.206 (discussing such an interpretation of Hobbes); Richard A. Musgrave, A Brief History of Fiscal Doctrine, in 1 HANDBOOK OF PUBLIC ECONOMICS 1, 16-18 (Alan Auerbach \& Martin Feldstein eds., 1985) (benefit taxation supported by Hobbes, Gortius and Locke). The most common interpretation of the Hobbes quote, however, is that Hobbes intended to focus on what an individual spends as the measure of comparison. See, e.g., NicHOLAS KALDOR, AN EXPENDITURE TAX 53 (1955). It is this perspective that later scholars adopt in forming the common pool analogy.

73 Although Mill is often credited with developing the concepts underlying the common pool analogy, Mill never actually used the term common pool. See Stephen G. UtZ, TaX Policy: An INTROduction and SuR vey of the Principle DEBATES 135, 136 (crediting Mill with the equity argument underlying the common pool analogy). The analogy, however, is used by both advocates and critics of consumption taxes historically and in current discussions. See, e.g., CHARLES FrIED, RIGHT AND WRONG 147 (1978) (advocating consumption taxes); THE 
labor and savings are characterized as contributions to the common pool while consumption is characterized as withdrawal of resources for personal use. ${ }^{74}$ Thus, income taxes have the perverse effect of levying taxes on those things that contribute to the common pool while consumption taxes fall only on withdrawals from the pool. ${ }^{75}$

InSTITUTE FOR Fiscal Studies, The Structure AND Reform of DiRect TAXATION: Report of a COMmitTEe Chaired by PROFEsSor J.E. MEAD 33 (1978) [hereinafter MEAD REPORT] (advocating consumption taxes); KALDOR, supra note 72, at 53 (advocating consumption taxes); Barbara Fried, Fairness and the Consumption Tax, 44 STAN. L. REv. 961, 962 (1992) (criticizing consumption taxes); McCaffery, supra note 1, at 338-39 (advocating consumption taxes); Warren, supra note 6, at 1094-95. See also UTZ, supra, at 135 (describing the debate); Alstott, supra note 1, at 375-76 (arguing that McCaffery's use of the common pool metaphor in the context of liberal theory is unpersuasive); HARVEY S. ROSEN, PUBlic FinANCE 452 (6th ed. 2002) (describing the debate and using the analogy without the words "common pool"); Murray L. Weidenbaum \& Ernest S. Christian, Jr., Shifting to Consumption as a Federal Tax Base: An Overview, in THE VALUEAdDED TAX: ORTHODOXY AND NeW ThINKING 1, 1 (Murray L. Weidenbaum, David G. Raboy \& Ernest S. Christian, Jr. eds., 1989) (using the analogy without the words "common pool"). Some scholars use the terminology of a common store of goods, rather than a common pool, in discussing taxation. See McCaffery, supra note 1, at 339-41; Rawls, supra note 25, at 278; Murphy, supra note 25, at 491 (referring to a "common store" analogy in evaluating contributions to society based on types of labor).

74 For example, Kaldor argues that it is the act of spending that places a burden on society, and it is therefore spending that should be burdened with taxation. See KALDOR, supra note 72, at 53.

Andrews offers a slightly different version of the reason for taxing consumption as an exhaustion of societal resources. According to Andrews, the purpose of taxation is to curtail private consumption. If private consumption is curtailed, resources that would have gone to private consumption may be used for public purposes, including fueling the economy. If one's purpose is to curtail private consumption, it is fair and efficient to tax private consumption. See William D. Andrews, A Consumption-Type or Cash Flow Personal Income Tax, 87 HARV. L. REV. 1113, 1165-66 (1974). Thus, Andrews suggests taxing spending less as a punitive measure for burdening society than as a practical one for creating incentives that will make resources available for the public.

75 For example, Kaldor describes income as one's "personal contribution to the wealth of others" and lauds "the praiseworthy activities of Working, Saving or Risk Taking." KALDOR, supra note 72, at 53.

For Mill, the fact that savings provide a common benefit to society means that savings should not be counted as income. The funds should not be credited to an individual for the purposes of taxation until the individual spends the money thereby dedicating the funds to unproductive personal consumption. Rather than advocating a tax on spending, however, Mill supports income taxes but defines income to exclude savings. See KALDOR, supra note 72, at 79-81; UTZ, supra note 73, at 97; see also John STUART Mill, PRINCIPLES OF POlITICAl ECONOMY: BOOKS FoUR AND FIVE 164-65 (Donald Winch ed., Penguin Books 1985) (1848) ("No income tax is really just from which savings are not exempted."). 
At the heart of this debate is the treatment of savings. To consumption tax advocates, when individuals save rather than spend, they leave money in the common pool where it provides benefits for the rest of us. There are two components of the characterization of savers as those who provide a benefit for the rest of us. First, savers are denying satisfaction of their current desires, an act that spares society the loss of resources that would have been used to satisfy those wants. Second, resources saved or invested increase the capital available for those who wish to create or expand productive enterprises. Greater availability of capital drives down interest rates and promotes economic expansion. ${ }^{76}$

The common pool analogy implies that resources are either dedicated to satisfying an individual's current desires or they are dedicated to the benefit of society, but that they cannot do both. A number of scholars have suggested, however, that resources saved may still satisfy some types of current desires. For example, greater wealth may bring intangible benefits such as greater power, security, prestige, and respectability. ${ }^{77}$

76 For a list of scholars arguing that shifting to a consumption tax will increase the national savings rate thereby resulting in a boost in productivity, see Fried, supra note 73, at 962 \& n.4. See also HALl \& RABUSHKA, supra note 2, at 83-104; Jorgenson, supra note 59, at 181; Malcolm Gillis, Peter Mieszkowski \& George R. Zodrow, Indirect Consumption Taxes: Common Issues and Differences Among the Alternative Approaches, 51 TAX L. REv. 725, 728-29 (1996) (citing numerical simulation suggesting that replacing income tax with consumption tax would produce significant increases in savings, investment, and economic growth); Judd, supra note 1, at 1-2 (most economists agree that moving to consumption taxes would improve long-run productivity).

A recent complex simulation finds that if the United States shifts to the Hall/Rabushka Flat Tax, the most popular of the current consumption tax proposals, long-term output would rise approximately $5 \%$. Altig et. al, supra note 1, at 576. With the inclusion of transition relief, long-term output would rise less than 2\%. Id. See also Engen \& Gale, supra note 59, at 111 (switching to a consumption tax would increase savings, but only by $.8 \%$ of GDP). Earlier, more limited simulations suggested that the economic effects of shifting to a consumption tax might be greater. See Auerbach, supra note 2; Anthony B. Atkinson \& Agnar Sandmo, Welfare Implications of the Taxation of Savings, 90 ECON. J. 529 (1980); P.A. Diamond, Taxation and Public Production in a Growth Setting, in MODELS OF ECONOMIC GROWTH 215 (J.A. Mirrlees \& N.H. Stern eds., 1973); M.S. Feldstein, The Rate of Return, Taxation, and Personal Savings, 88 EcoN. J. 482 (1978).

In addition, the following studies conclude that eliminating taxation of asset income, which would be the effect of consumption taxes, will stimulate long-term economic growth. See J. Eaton, Fiscal Policy, Inflation and the Accumulation of Risky Capital, 48 Rev. ECON. STUD. $435-45$ (1981); Kenneth L. Judd, Optimal Taxation and Spending in General Competitive Growth Models, J. PUB. ECON. (1999).

77 See Fried, supra note 73, at 963; Henry C. Simons, Personal InCome Heinonline -- 21 Va. Tax Rev. 325 2001-2002 
In addition, the notion of forgoing current desires summons up an image of self-sacrifice. Savers are cloaked with the mantle of moral superiority, lauded for their ability to stave off the baser human desire for instant gratification. This image of moral superiority has been greeted with some skepticism. The notion that capitalists should be rewarded for the pain of waiting is tough to swallow when the capitalist class seems unlikely to be the portion of society in the greatest pain. As Solow suggests, characterizing the return to capital as compensation for the pain of waiting for consumption would have more resonance if it weren't for the fact that so many capitalists seem to do their waiting in limousines. ${ }^{78}$ As a result of such criticism, modern consumption tax advocates tend to focus on the second aspect of the saver analysis. In the modern view, the key is not that resources saved are unavailable to the saver, but that those resources coincidentally provide benefit to the rest of society by promoting economic growth. ${ }^{79}$

Taxation: The Defintion of Income as a Problem of Fiscal Policy 97 (1938). See also Fried, supra note 73, at 964 (citing RICHARD GoOdE, THE INDIVIDUAL INCOME TAX 22 (1964) for the proposition that the common pool analogy is also open to attack on the ground that the power to direct one's own investments as one sees fit is a private appropriation). In addition, resources saved may translate into tangible consumption opportunities. Modern lenders are remarkably creative in helping investors find ways to unlock current benefit without liquidating investments. Thus, even though individuals have forgone current consumption, they have still gained current benefit.

78 Robert M. Solow, Capital TheORY and the RATE OF RETURN 10-11 (1965) ("Since so much of the 'waiting' gets done in expensive automobiles and luxurious resorts, while the 'abstinence' excites little sympathy in an even slightly cynical observer, the whole apparatus begins to look like a transparent verbal trick."). Barbara Fried, tracing the history of the debate over whether interest compensates for the psychological pain of forgoing current consumption, quotes Lassalle's famous diatribe:

The profit of capital is the 'wage of abstinence.' Happy, even priceless expression! The ascetic millionaires of Europe! Like Indian penitents or pillar saints they stand: on one leg, each on his column, with straining arm and pendulous body and pallid looks, holding a plate towards the people to collect the wages of their Abstinence. In their midst, towering up above all his fellows, as head penitent and ascetic, the Baron Rothschild! This is the condition of society! How could I ever so much misunderstand it!

Fried, supra note 73, at 970-73 (citing Ferdinand LaSAlle, KAPITAL UND ARBEIT 110 (Berlin 1864)).

79 See supra note 76 (citing sources predicting that consumption tax will increase savings rate and promote economic growth). If individuals fail to consume anything with their money, there is no guarantee that the money will automatically create economic stimulus. For example, those who do not consume all of their 
The notion that saving benefits all of society could suggest that savers should receive more favorable treatment than spenders in a tax system. The income tax system certainly does not favor savers over spenders. In fact, consumption tax advocates argue that the income tax system discriminates against savers. ${ }^{80}$ This remains a key argument for most consumption tax advocates today ${ }^{81}$ and can be described in the following manner: In an income tax world, one who reaches a spending goal by saving over time has less spending power than one who earns money and spends it immediately. This occurs as a result of taxing the returns to savings. Thus, comparing an income tax world to a no-tax world, spenders fare better than savers. ${ }^{82}$

income need not invest the money. They could simply put it under the mattress. Such individuals are a variation on Fried's inframarginal saver, that is, one who will save rather than spend at an interest rate lower than the present one. Fried, supra note 73 , at $969 \mathrm{n} .24,982-85$. Those who stash their cash under a mattress are inframarginal savers with a zero interest rate preference. That type of consumption restraint would not stimulate economic expansion. Similarly, all money invested does not necessarily create economic stimulus, and all investments do not create the same amount of economic stimulus. An investment in antique cars, for example, is unlikely to provide the same boost to the economy as an investment in expanding and updating manufacturing capabilities.

It may be more accurate to think of some low-yielding investments as partconsumption. One who buys antique cars may be willing to receive less interest on an investment because of the joy of ownership. It would be difficult, as a practical matter, to treat investments as part consumption and part investment. In addition, one might then argue that differences in risk tolerance should be treated as consumption. For example, we know that some people choose investments with lower returns in order to satisfy their demand for lower risk. Should we characterize lower risk tolerance as a form of consumption, that is, purchasing a measure of security? Regardless of whether we treat investments as part consumption, the notion that when individuals forgo consumption they create economic stimulus is somewhat simplistic. The amount of economic stimulus may vary and, in extreme cases, may not exist at all.

80 KALDOR, supra note 72 , at 80-81 (describing an early version of this analysis in Mill's writing and advocating consumption taxes).

81 See McLure \& Zodrow, supra note 2, at 71 (noting that one of the most prominent advantages of consumption taxes is their neutrality toward the choice between spending and saving); see also MICHAEL BOSKIN, AN ECONOMIST'S Evaluation of the Political Discourse on Fundamental TaX Reform Proposals 8 (Center for Econ. Policy Research 1995) (Publication No. 446) (noting the argument).

82 Fried describes the argument in detail in her critique of consumption tax theory. Fried, supra note 73, at 963-964 \& n.10 (citing ANTHONY B. ATKINSON \& Joseph E. Stiglitz, Lectures on Public Economics 71 (1980)); DaVId F. BRADFORD, UNTANGLING THE INCOME TAX 162 (1986).

Andrews presents the classic description of the spender/saver penalty. See Andrews, supra note 74 , at 1168 . He illustrates the problem by comparing two taxpayers, each of whom needs the same amount to spend. Andrews uses $\$ 8$ in his 
The spender/saver penalty argument is presented both as an equity argument and an economic growth argument. From a growth perspective, consumption tax advocates argue that removing the saver penalty will encourage saving and promote economic growth. ${ }^{83}$ From an equity perspective, consumption tax advocates argue that an income tax is unfair because it treats two similarly situated taxpayers differently. ${ }^{84}$

example. I will use $\$ 800$ to eliminate decimals and simplify the hypothetical. In addition, in Andrews' world, the tax rate is $33 \%$ and individuals receive $9 \%$ interest on investments.

One taxpayer earns $\$ 800$ the first year and spends it all immediately. The other earns $\$ 100$, saves all of it and reinvests the interest until he has $\$ 800$. In a world without taxes, the two would each have the same amount to spend- $\$ 800$. Similarly, in a consumption tax world, the two will each have the same amount to spend after taxes-\$533. In an income tax world, however, the one who spends immediately will have $\$ 533$ to spend after tax, while the saver will only have $\$ 267$ to spend after taxes.

The example can be illustrated with the following chart:

\begin{tabular}{|c|c|c|c|c|c|}
\hline & $33 c$ & $\begin{array}{r}\text { The Sa } \\
\text { ax; } 9 \% \text { intere }\end{array}$ & $\begin{array}{l}\text { ver Penalty } \\
\text { st; } 24 \text { yrs com }\end{array}$ & pounding & \\
\hline NO TAX & WORLD & INCOME TA & $A X$ & CONSUM & IION TAX \\
\hline Spender & Saver & Spender & Saver & Spender & Saver \\
\hline $\begin{array}{l}\$ 800 \\
\text { salary }\end{array}$ & $\begin{array}{l}24 \text { yrs ago } \\
\text { earned } \$ 100\end{array}$ & $\begin{array}{l}\$ 800 \\
\text { salary }\end{array}$ & $\begin{array}{l}24 \text { yrs ago } \\
\text { earned } \$ 100\end{array}$ & $\begin{array}{l}\$ 800 \\
\text { salary }\end{array}$ & $\begin{array}{l}24 \text { yrs ago } \\
\text { earned } \$ 100\end{array}$ \\
\hline & $\begin{array}{l}\text { put } \$ 100 \text { in } \\
\text { savings at } \\
9 \% \text { interest }\end{array}$ & $\begin{array}{l}33 \% \text { income } \\
\operatorname{tax}\end{array}$ & $\begin{array}{l}\text { put } \$ 100 \text { in } \\
\text { savings at } \\
9 \% \text { interest }\end{array}$ & spends all & $\begin{array}{l}\text { puts } \$ 100 \text { in, } \\
\text { no tax on } \\
\text { interest }\end{array}$ \\
\hline & has $\$ 800$ & $\$ 533$ left & $\begin{array}{l}33 \% \text { tax each } \\
\text { yr on interest } \\
\text { (nets only } 6 \% \\
\text { interest) }\end{array}$ & $33 \%$ tax & $\begin{array}{l}\text { has } \$ 800 \text {; } \\
\text { spends all; } \\
\text { pays } 33 \% \\
\text { consump- } \\
\text { tion tax }\end{array}$ \\
\hline
\end{tabular}

Dollars To Spend:

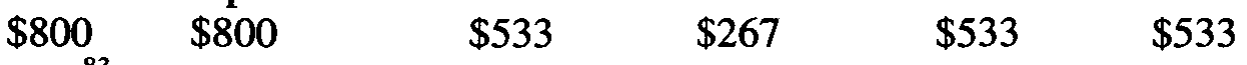

in 24 yrs

has $\$ 267 \quad \$ 533$ left $\$ 533$ left

83 See sources cited supra note 76.

84 See, e.g., David F. Bradford and the U.S. Treasury Tax Policy STAFF, BLUEPRINTS FOR BASIC TAX REFORM 9 (2d ed. revised 1984) (consumption tax more equitable than income tax because income tax treats taxpayer differently depending on the time pattern of their earnings and how they allocate spending among time periods). Consumption tax critics respond that the two taxpayers may not be similarly situated, and that the logic of the hypothetical is circular. The penalty hypothetical compares two citizens who differ in terms of income, savings, 
Other equity arguments arise in the consumption tax debate over the distributional effects of a consumption tax. Shifting from a consumption tax to an income tax will provide great benefits to those who save. It turns out that those who save also happen to be those who have more. ${ }^{85}$ When life-cycle effects are included, consumption

and the timing of consumption, and argues that they are treated unfairly because they don't have equal consumption power across time. Perhaps wealth, income, or something else is the proper basis for comparing citizens rather than consumption across time. It is difficult to argue that consumption is the proper basis for comparing citizens by using a hypothetical that assumes consumption is the proper basis for comparing citizens. See Fried, supra note 73, at 1006-07; see also RICHARD A. Musgrave, The Theory of Public Finance: A Study in Public Economy 16263 (1959). Kelman also criticizes the spender/saver argument on the ground that different perceptions of the reasons people save and the origin of interest affect whether the spender and saver are similarly situated. Mark Kelman, Time Preference and Tax Equity, 35 STAN. L. REV. 649, 656-58 (1983).

In addition, Fried develops an extensive criticism of the spender/saver penalty, arguing that the penalty does not apply to all savers or to all components of the return to savings. Fried, supra note 73, at 1004-06 \& nn.74-78.

85 Mill acknowledges the possibility that the rich will benefit from consumption taxes and responds:

It has been further objected, that since the rich have the greatest means of saving, any privilege given to savings is an advantage bestowed on the rich at the expense of the poor. I answer, that it is bestowed on them only in proportion as they abdicate the personal use of their riches; in proportion as they divert their income from the supply of their own wants, to a productive investment, through which, instead of being consumed by themselves, it is distributed in wages among the poor. If this be favouring the rich, I should like to have it pointed out, what mode of assessing taxation can deserve the name of favouring the poor.

MiLL, supra note 75 , at 165 . Andrews, however, suggests that it is the poor, rather than the rich who will turn out to be the savers. "At any particular income level, however, it seems reasonable to assume that those with more wealth will feel free to spend more and save less." Andrews, supra note 74, at 117. Thus, the benefits of consumption taxes would be more evenly distributed. But see PAUL SAMUELSON, ECONOMICS, (9th ed. 1973) (consumption is a declining fraction of income); Franco Modigliani \& Richard Brumberg, Utility Analysis and the Consumption Function: An Interpretation of Cross-Section Data, in POST-KEYNESIAN ECONOMICs 388, 408-09 (Kenneth K. Kurihara ed., 1954). Despite Andrews' supposition, studies conclude that the greatest benefits from shifting to a consumption tax usually would go to the highest income earners. See Joseph Bankman \& Barbara Fried, Flatness and Fairness, Boston REVIEW 3, 4 (Summer 1996) (even consumption tax advocates Hall \& Rabushka admit that shifting to a consumption tax with flat rates will be a boon to the economic elite); McLure \& Zodrow, supra note 2, at 72 (shifting to Hall/Rabushka Flat Tax would decrease tax burden on wealthiest and increase burden on the poorest); Gale, Houser \& Scholz, supra note 60, at 297, 299-300 (shifting to the Hall/Rabushka Flat Tax or a VAT would greatly reduce taxes for the highest earning taxpayers; however, the USA tax, another consumption-based tax proposal, would increase taxes on the top earners); see also 
tax simulations show less of a burden on some members of the lifetime poor. ${ }^{86}$ The strongest benefits, nevertheless, accrue to those at the very top of the scale. ${ }^{87}$

Consumption tax advocates point to one other advantage of consumption taxes: simplicity. Everyone agrees that the current income tax system is horribly complicated. ${ }^{88}$ Many of these complications flow from the difficulty of devising a consistent and effective approach to taxing gain on savings. ${ }^{89}$ A consumption tax system bypasses these problems by taxing only spending rather than saving. ${ }^{90}$

JosePh A. Pechman, Who Paid the TaXes: 1966-85 (1985) (shifting to a broadbased VAT would be regressive).

86 Until recently, consumption tax simulations used data that considered only a snapshot view of each person's finances. A person who had little money at the snapshot moment was designated a poor person. Thus, when the study concluded that consumption taxes hurt the poor, the poor would have included law students and surgery residents, individuals who are perhaps not prime examples of underprivileged members of society. See, e.g., Gale, Houser \& Scholz, supra note 60, at 281-82 (given difficulties of obtaining accurate lifetime data, only annual distributional analysis is used); see also Gilbert E. Metcalf, The Role of a Value-Added Tax in Fundamental Tax Reform, in FRONTIERS OF TAX REFORM 91, 100 (Michael J. Boskin ed., 1996) (criticizing Pechman's work as based on annual rather than life time analysis). Simulations considering life-cycle effects try to produce a fuller picture of a person's resources across a lifetime. See, e.g., Altig et al., supra note 1.

87 See Altig et al., supra note 1, at 576.

88 See, e.g., HALL \& RABUSHKA, supra note 2, at 1 (containing quotes on the complexity and incomprehensibility of the American income tax system); BRADFORD, supra note 84, at 1 (lamenting the complexity of the current American system and citing Treasury Secretary Simon's comment that the nation should "have a tax system which looks like someone designed it on purpose").

${ }^{89}$ As Andrews demonstrates

Most of the problems that occupy most of the time of tax practitioners and administrators (not to speak of teachers, students, legislators, and taxpayers themselves) arise immediately out of our failure to take a consistent and comprehensive position with respect to inclusion or exclusion of real accumulation in taxable income.

Andrews, supra note 74, at 1140; see also McLure \& Zodrow, supra note 2, at 71 (income taxation is inherently complex because complicated timing rules are needed). Andrews notes further that although the government could solve these problems by taxing all unrealized appreciation, this approach would be enormously impractical. See Andrews, supra note 74, at 1141.

90 Not all scholars agree that consumption taxes would be as simple as projected. See Weisbach, supra note 1, at 599; see also Joel Slemrod, Which is the Simplest Tax System of Them All?, in ECONOMIC EFFECTS OF FUNDAMENTAL TAX REFORM 355, 380-81 (Henry Aaron \& William G. Gale eds., 1996) (shifting to a consumption tax is neither necessary nor sufficient for tax simplification); McLure \& Zodrow, supra note 2, at 71 (simplicity not inevitable in consumption taxes; potentially simple consumption tax can be made complex just as the present inHeinonline -- $21 \mathrm{Va}$. Tax Rev. 330 2001-2002 


\section{B. Consumption Tax Arguments: The Philosophical Roots}

Each of the arguments presented in favor of consumption taxes falls within the categories of moral philosophy described earlier in this article: welfarist, weighted welfarist, and nonconsequentialist. The following section analyzes the philosophical roots of the consumption tax arguments.

As described above, nonconsequentialists would evaluate a tax proposal based on how well it conforms to moral norms. A number of the consumption tax arguments follow this path, although using varying visions of the core moral norms. For example, consider the common pool argument that when individuals consume, they dedicate resources to private uses, making those resources unavailable to others. Consumption taxes are good, therefore, because they discourage the behavior that makes resources unavailable to others. ${ }^{91}$

The argument could be recast as a rights argument based on the rights of society rather than individual rights. The notion that consumption should be taxed because consumption places a burden on society could imply that society owns the goods or has a general claim to the resources. Thus, when citizens use resources for private use, the "rights" that have been transgressed are society's rights to use the resources for the common good. ${ }^{92}$

One could also think of taxation as operating in the realm in which individuals' claims to resources intersect with society's claims to using resources for the common good. ${ }^{93}$ Thus, society may not have a claim to all resources, just to those necessary for public purposes. Regardless of whether the core values protected are individual rights or society's rights, this consumption tax argument takes a non-

come tax is far more complicated than it needs to be).

91 See Kelman, supra note 84, at 651-52 (criticizing consumption taxes and describing consumption tax advocates' view of taxation as punishment for spending).

92 One could think of society as nothing more than a combination of individuals. Thus, one could argue that the notion of society's rights is still really a notion of individual rights. The person who has consumed has infringed on the rights of a large number of people, and we just choose to call them collectively "society." This version of society, however, is less responsive to the notion of using resources for the common good. It is useful to think of society as a collective entity with its own rights in order to include the notion that resources could be used collectively.

93 This argument would be consistent with Andrews's view that the purpose of taxation is to curtail private consumption so that resources that would have gone to private consumption may be used for public purposes. See Andrews, supra note 74 , at 1165-66. 
consequentialist approach in which the tax is evaluated by examining whether it is faithful to core moral values.

Other consumption tax arguments are based on the core moral notion that individuals have the right to the fruits of their labor. Thus, income taxes are inferior because they reduce the fruits of one's labor.

Some aspects of the common pool argument also reflect a desire to protect citizens' rights to the fruits of their labor. For example, savers, those who refrain from spending, delay the enjoyment of the fruits of their labor in a way that benefits society. Consumption taxes, which treat savers better than income taxes treat savers, show greater respect for the right to the fruits of one's labor and for the sacrifice inherent in forgoing immediate enjoyment of those fruits.

The nonconsequentialist arguments described above reflect the core moral values of (i) rights to the use of resources and (ii) rights to the fruits of one's labor. Other consumption tax arguments reflect the core moral norm that society should provide a just reward for virtuous behavior. This is not a utilitarian argument that we should reward people to encourage good behavior in an effort to maximize value for everyone. A nonconsequentialist would compensate those who behave virtuously even if this does not result in increasing society's good. In other words, if those who behave virtuously would do so anyway, regardless of whether society or the tax system compensates them, a nonconsequentialist could argue that compensation is appropriate as their just reward.

Consumption tax arguments also are consistent with core moral norms for choice theorists who hold that individuals are entitled to the resources and opportunities that flow from their own efforts and choices. A choice theorist might value consumption taxes from the perspective that consumption taxes respect the fruits of one's labor as well as one's spending choices while welcoming subsidiary norms that provide for some redistribution on the grounds that the fruits one receives are not entirely due to one's own labor. ${ }^{94}$

Some of the consumption tax arguments reflect both nonconsequential arguments and welfarist theories. For example, the spender/saver penalty argument contains both a rights-based, equity argument and a utilitarian/welfarist argument. From a rights-based perspective, consumption tax advocates would argue that a core moral good for a tax system is its ability to treat taxpayers equally. An income tax is flawed in that it disfavors future consumption in

94 See supra text accompanying notes 53-56 (describing this nonconsequentialist approach). 
comparison to present consumption. A consumption tax, in which current and future consumption are treated in a way that is comparable to a no-tax world, presents a system that conforms better to notions of equity.

The spender/saver penalty argument also reflects a welfarist perspective. Recall that welfarists would evaluate a tax plan based on its ability to maximize the satisfaction of individual preferences as a whole. In modern economic terms, the ability to maximize preferences is measured by reference to economic growth. Consumption tax advocates argue that the spender/saver penalty depresses savings rates and dampens economic growth. Thus, eliminating the spender/saver penalty would help maximize individual preferences.

The argument that savers should be rewarded because saving benefits all of society also reflects a welfarist perspective. In contrast to the nonconsequentialist arguments for rewarding savers, welfarists would reward savers to provide incentives for behavior that will promote economic growth. Thus, from a welfarist perspective, consumption taxes maximize individual preferences by providing incentives for behavior that stimulates the economy.

This welfarist perspective applies not only to the treatment of savers but also to the full comparison of consumption taxes and income taxes. The notion that consumption taxes reward the productive activities of work and saving while discouraging the nonproductive use of resources follows the welfarist dictate that taxation should provide incentives for behavior that maximizes economic growth.

The simplicity argument also can be categorized as a welfarist argument. Simpler tax systems are preferred because they are more efficient and therefore less of a drag on the economy.

Finally, some of the consumption tax arguments reflect a weighted welfarist perspective. Weighted welfarists view maximizing preferences as the primary consideration but allow weighting or ranking of preferences. Weighted welfarism appears in the consumption tax literature through concern over the distribution of wealth. Thus, the primary issue is maximizing overall growth, while distribution of wealth is a subsidiary concern. ${ }^{95}$ The subsidiary issue enters as a utilitarian point. For example, in light of declining marginal utility, transfers of wealth, at least up to some unknown level, may maximize preferences. ${ }^{96}$

95 See, e.g., Judd, supra note 1 (noting that consumption taxes promote economic growth and provide better distributional effects than critics claim).

96 See Fried, supra note 73, at 1017 (noting that one could support a consumption tax on the utilitarian/welfarist grounds that exempting the return to capital with redistributive transfers by the government might maximize aggregate well- 
A weighted welfarist could conceivably borrow a page from choice theory and argue that if people are rewarded only for things that flow from their own efforts and choices, they will be encouraged to make prudent choices that maximize overall utility. In particular, if those endowed by the pleasant fortune of being born into a favored race and class cannot retain the financial benefit of serendipity, they may decide to work harder. I suspect, however, that choice theorists would vehemently object to supporting a utilitarian analysis. ${ }^{97}$ In addition, utilitarians may respond that it would be difficult to design a system that redistributes unmerited good fortune without discouraging work efforts.

\section{Which Consumption Tax Arguments Could Support a System Regardless of How Well it Captures Individual Consumption?}

The arguments in favor of consumption taxes fall with the categories of moral philosophy described earlier in this article: welfarism, weighted welfarism, and nonconsequentialism. The following section examines which of the consumption tax arguments could support a system regardless of how well it captures individual consumption.

The nonconsequentialist arguments in favor of consumption taxes are based on respect for the following five core moral values: (i) rights to resources; (ii) the right to the fruits of one's labor; (iii) a just reward for virtuous behavior; (iv) entitlement to the resources and opportunities that flow from one's own efforts and choices; and (v) equal treatment for equivalent taxpayers. The level of respect for these values is measured by scrutinizing the government's response to the consumption activity of individual taxpayers. In a system that fails to capture individual consumption, however, the government's response is not tailored to the individual activity of citizens. Such a system could not satisfy the goals expressed in these nonconsequentialist arguments.

For example, consider the argument that by dedicating resources to personal use, an individual infringes on society's rights to resources, and the government should penalize such behavior. This argument fails if the tax system does not match its response to an

being).

One could present the subsidiary distributional issue as a nonconsequentialist point, for example by arguing that notions of equality should be considered in addition to, or subordinate to, maximization of preferences through economic growth.

97 See Rakowski, supra note 49, at 283, 285 (setting aside utilitarian theories of justice to apply a choice theoretical perspective and arguing that "it is a profound error to tie the justice of a state of affairs wholly or mainly to people's welfare"). 
individual's behavior. Similarly, consider the argument that the spender/saver penalty in income taxes creates an inequity between those who consume currently and those who consume in the future. The goal in correcting this problem would be to tax each individual equally based on what each individual consumes. If the tax system does not tax each individual for that individual's level of consumption, the system cannot meet such a goal.

In sum, none of the nonconsequentialist arguments can support a system that fails to tax individual consumption. Each one is based on a vision in which the tax system responds to each person's consumption behavior. As the system moves away from matching people's taxes to their level of consumption, it moves away from the theoretical goals presented. ${ }^{98}$

In theory, a simplified welfarist argument could be constructed in a way that would be consistent with a general consumption tax. As described above, pure welfarism attempts to maximize the sum of the satisfaction of all preferences as measured by gains in the economy overall. Current consumption tax models generally are grounded in predictions of how individuals will respond to the incentive effects of being taxed on what they consume. ${ }^{99}$ If individuals are not fully taxed on their levels of consumption, however, one cannot count on the incentive effects predicted by the models. It is possible that the proposals still lead to economic growth, but the current modeling would have to be changed to predict and account for the altered incentive patterns.

Some weighted welfarist theories would be consistent with a tax that fails to capture individual consumption, but many would not. Recall that weighted welfarists strive towards maximization but also weight or rank preferences in pursuit of the best resulting state of affairs. Suppose that the ranking relates to consumption. For example, imagine the following weighted welfarist argument in favor of

98 It would be extraordinarily difficult to construct a nonconsequentialist theory with goals that can be met by capturing all of an activity throughout society. Such goals could not relate to individual rights, given that the system would be blind to the activities of the individual, and nonconsequentialism cannot be satisfied by protection of rights in the aggregate. In addition, the goals could not depend on providing incentives to individuals because a system of general taxation does not match its level of response to an individual's level of activity. Regardless of whether one could construct such a theory, however, the nonconsequentialist arguments offered in favor of consumption taxes do not take this approach.

99 See, e.g., Altig et. al, supra note 1; Judd, supra note 1; see also ECONOMIC EFFECTS OF FUNDAMENTAL TAX REFORM, supra note 1. Although welfarists look at the overall results, the results are based on a summation of the effects on individuals. See supra note 22 and accompanying text. 
shifting to the modern tax proposals: The modern proposals are preferable to the current system because the proposals maximize overall welfare as measured by economic growth. Although the distributional effects of the proposal do favor those who have more over those who have less, this effect is consistent with respect for individual choices expressed through consumption and savings. Although some distributional differences flow from serendipitous advantages unrelated to anything for which we should receive moral credit, such distributional inequities can be alleviated by progressivity measures in the proposals. ${ }^{100}$

Such a theory, grounded in weighted welfarism, would not be consistent with a tax that fails to capture individual consumption. If the tax does a poor job of matching tax burdens with actual levels of consumption, the system does a poor job of respecting individual choices related to consumption or nonconsumption.

In contrast, one could imagine a weighted welfarist theory, in which the ranking relates to something other than consumption or nonconsumption, that could support a general consumption tax. For example, suppose the ranking relates to simple distribution. In other words, imagine a weighted welfarist theory in which maximizing economic growth is the primary objective while ensuring some level of redistribution is the secondary consideration. If the modern proposals could be altered to accomplish redistribution of wealth, one could then support the proposals on the grounds that they would increase economic growth and accomplish redistribution.

The proposals, as currently drafted, do not have the effect of redistributing wealth from those who have more to those who have less. One should at least acknowledge the possibility, however, that a tax proposal could be drafted that satisfied the primary goal of economic growth as well as a secondary goal, unrelated to consumption, such as redistribution.

In sum, none of the nonconsequentialist theories could support a system that fails to tax individual consumption. Those weighted welfarist theories in which the ranking relates to taxing citizens for what they consume also could not support a system that fails to tax individual consumption. One could imagine a weighted welfarist theory, one in which the ranking relates to something other than consumption, that could support a consumption tax regardless of how well it captures individual consumption. None of the weighted welfarist theories offered in support of the modern proposals, however, takes

${ }^{100}$ Such measures could include exemptions of certain amounts of wages, exemptions of certain types of consumer items such as basic necessity, and a progressive rate structure. 
this approach. The only consumption tax theory that can fully support a tax that fails to capture individual consumption is a pure welfarist theory in which the only goal is increased economic growth. Even pure welfarists, however, would have to be able to predict and account for the altered incentive patterns of the failure to fully tax individuals on what they consume.

\section{IMPLEMENTING CONSUMPTION TAXES}

The previous section described consumption tax theories and analyzed which theories would be consistent with a consumption tax that failed to tax individual consumption. The following section describes methods of implementing consumption taxes and identifies features of the modern proposals that move the proposals away from individual taxation and towards general taxation.

\section{A. The Mechanics of Taxing Consumption}

If the government wishes to tax people on the amount they consume the most direct approach would be to collect tax from people whenever they consume something. Collecting the tax precisely at the moment of consumption, however, could be difficult. The consumer may not be engaging in a monetary transaction at the moment of consumption. Without a monetary transaction, the government does not have an easy way to value the item consumed and cannot piggyback its own monetary collection process onto one that is already taking place.

For example, consider the case of consumed goods such as groceries. Most people who buy a can of tuna at the Safeway do not open the can and consume it in the check out line. Although the monetary transaction occurs at the grocery store, the moment of consumption does not. To collect the tax at the moment of consumption, the taxing authority must appear at the taxpayer's house when the sandwich is served, a method of taxation that would be both burdensome on the government and intrusive to the taxpayer.

The difficulty of reaching citizens at the precise moment of consumption explains why governments often tax citizens when they purchase goods and services rather than when they consume. Governments who use this approach to collecting consumption taxes generally rely on the merchants, the providers of goods and services, to collect the tax along with the merchant's regular bill. This type of consumption tax system, known as a retail sales tax, is used by many jurisdictions throughout the world. 
The shortcut eases administration of the tax even though it fails to precisely capture consumption. For example, the can of tuna may sit on a shelf unopened for quite some time, and the sweater you purchased may never be worn, let alone worn out. ${ }^{101}$ Thus, retail sales taxes attempt to tax citizens on what they consume at the point of purchase, if not precisely at the point of consumption. ${ }^{102}$

One could also tax individuals on what they consume by taxing citizens periodically for their total amount of consumption. Thus, rather than asking merchants to collect the money at the point of purchase, the taxing authority would have to collect taxes from the individual. In addition, the individuals would have to keep track of the amounts that they had consumed.

The government could ask taxpayers to track the amount they consume by keeping receipts for all purchases made during the year. ${ }^{103}$ This approach, however, would be extraordinarily burden-

101 One might argue that it is irrelevant whether the item has been used up. Rather, consumption occurs when an item is withdrawn from the common pool (goods available to everyone) and dedicated to personal needs. It does not matter whether the individual actually exhausts the resources if it is no longer available to others. Many consumption tax advocates, however, describe consumption in terms of exhausting a valuable resource. See, e.g., Utz, supra note 73, at 138 (consumption is using up something of value in a way that returns nothing to the common store); Warren, supra note 8, at 1084 (consumption means the ultimate use or destruction of economic resources such as drinking a glass of wine); $c f$. IRVING FISHER, THE THEORY OF INTEREST 9-10 (1930) (domestic spending is good measure of what an individual uses up).

102 In fact, no tax system can hope to collect taxes at the precise moment that the taxable event occurs. It is too difficult to determine when the actual event has occurred, and it would require a system that is far too intrusive and expensive to administer. For example, in order to tax income in this manner, the government would have to determine the precise moment each item of income is earned. In the case of wages, you earn a little every day you go to work -in fact, every minute that you are at work. The government would have to install a meter at your work location for you to feed every minute. In the case of capital gains, the government would have to determine when the value of your house increases and by how much. Given the difficulties, tax systems must compromise in at least two ways: first, by choosing a point in time that approximates the time of the actual event, and second, by looking periodically at all the taxable events that have occurred rather than tracking each citizen moment by moment. Although future technology conceivably could allow us to track each citizen moment by moment, technology is unlikely to solve questions surrounding when an event occurs. In addition, we may not wish to live in a society that tracks our activities by the second.

${ }^{103}$ Although this approach may seem ludicrous, the federal government used a similar approach in another context in the early 1980s. Taxpayers, who were allowed to take a federal tax deduction for all state sales taxes, kept track of all cash register receipts that listed sales tax. At the end of the year, the taxpayer added up the tax listed on the receipts and took a deduction from federal income taxes. Those who wished to avoid this process could take advantage of a standard deduc- 
some on taxpayers. One could avoid the cumbersome process of collecting receipts, however, by simply assuming that individuals have consumed any resources they have not saved. This is the basis of a cash flow consumption tax. ${ }^{104}$

A typical cash-flow consumption tax uses the vehicle of a qualified savings account. Anything deposited in the account is not taxed on the assumption that it is saved or invested. Anything withdrawn from the savings account is taxed on the assumption that the taxpayer will use the money for consumption. ${ }^{105}$ Once deposited in the qualified savings account, the funds can be invested in a variety of vehicles including stocks and bonds. Any investment gains are untaxed until the taxpayer withdraws money from the account.

To calculate tax liability under this version of a cash-flow consumption tax, taxpayers begin with their wages and subtract any amounts deposited in the qualified savings account. The taxpayer must then add any amounts withdrawn from the account. The final total is taxable as representing the taxpayer's consumption for the year.

Cash-flow consumption taxes would have the effect of taxing people for what they consume. The main design difficulties for this tax system involve the treatment of expenditures that are part consumption and part investment, such as housing, and the decision of what qualifies for the qualified savings account.

tion. Congress eliminated the deduction for state retail sales taxes as part of the 1986 tax act, and taxpayers stopped hoarding shoeboxes of register receipts.

104 The terminology in this area is somewhat counterintuitive. Tax scholars refer to a cash-flow consumption tax as a "direct" tax because the government collects the tax directly from citizens in a year-end tax return. See McLure \& Zodrow, supra note 2 , at 70 . Indirect taxation occurs when the government collects tax from businesses, which are expected to pass the tax on to consumers. See id. Thus, a tax on business profits is an indirect tax on the theory that the business will pass the cost of the tax on to consumers. A retail sales tax is also considered an indirect tax because the government collects the actual tax money from the business, not directly from consumers. See id. (indirect taxes include retails sales tax, value-added tax and business transfer tax).

One could also imagine using the opposite terminology. A cash flow consumption tax could be described as an "indirect" tax because the level of consumption is measured indirectly. In contrast, a retail sales tax directly measures each moment of consumption by taxing each individual purchase.

${ }^{105} \mathrm{See}$ ECONOMIC EFFECTS OF FUNDAMENTAL TAX REFORM, supra note 1, at 12-

13 (describing the so-called USA tax). 


\section{B. Value-added Tax}

The modern consumption tax proposals are all variations of a value-added consumption tax. Like the retail sales tax, VATs focus on taxing the sale of goods. ${ }^{106}$ VATs, however, are not collected in a lump sum when the final good is purchased. Rather, a VAT is collected piecemeal, a little bit at each stage in the production and distribution process. ${ }^{107}$

In theory, the price of any given product should include the costs of the inputs plus the wages of the workers plus the profits. In a VAT, the government has already taxed the firm that sold the inputs for the value of those inputs. Thus, to calculate the taxable value added at any stage, the government will measure the firm's sales less the costs of the inputs.

In addition to costs such as rent and physical inputs, a firm also incurs the cost of capital investments such as new plants or new equipment. In a consumption VAT, these costs are immediately deductible as well. After all, the goal of consumption taxes is to exempt savings and investment while applying taxes only when consumers use up a final product. Capital purchases are viewed as investments rather than sales of goods that will be used up by consumers. ${ }^{108}$ In summary, the firm determines its tax by calculating sales

106 For a description of the advantages of VATs over retail sales taxes, see OfFice of THE SEC'y, TREASURy DeP'T REPORT to THE PREsident, 3 TAX REFORM FOR FAIRNESS, SIMPLICITY, AND ECONOMIC GROWTH 31-33 (1984) [hereinafter 1984 TREASURY REPORT]. See also, Auerbach, supra note 2, at 29, 44-45 (describing how the Hall/Rabushka Flat Tax differs from a VAT).

107 There are three classic methods of implementing a value-added tax: 1) the subtraction method; 2) the credit/invoice method; and 3) the addition method. The proposals discussed in this article all use the subtraction method. To avoid putting readers to sleep, I will describe only the subtraction method. For a detailed description of all three methods comparing their strengths and weaknesses, see 1984 TREASURY RePORT, supra note 106, at 7-11. See also STAFF OF THE JOINT COMM. ON TAXATION, 105TH CONG., IMPACT ON INDIVIDUALS AND FAMILIES OF RePlacing THE Federal InCOME TAX (April 14, 1997), in Daily Tax Congressional Highlights \& Documents 667, 696-97 (April 15, 1997) [hereinafter 1997 JOINT COMMITTEE ON TAXATION]. Finally, readers should note that some scholars refer to the subtraction method VAT as a Business Transfer Tax or a BTT. See McLure \& Zodrow, supra note 2, at 87.

108 The value-added tax described above is a consumption tax. The total amount taxed should equal total private consumption. See 1984 TREASURY REPORT, supra note 106, at 7. VATs also can be designed to tax total income or total production. The difference hinges on the treatment of capital purchases. In a consumption VAT, the firm does not pay tax on any purchase of capital equipment in the year the company makes the purchase. In other words, the full cost is immediately deductible. In an income VAT, the firm does not get to immediately deduct 
for the year minus the cost of inputs and capital investments incurred during that year. The remaining amount, which is the value added at that stage by the firm and the workers, is taxable. ${ }^{109}$

\section{Regressivity: A Problem for VATs and Retail Sales Taxes}

As described above, shifting from an income tax to a consumption tax would be regressive. In other words, poor citizens would shoulder greater tax burdens under a consumption tax than they would under an income tax. ${ }^{110}$ In addition, regressivity problems are easier to fix in an income tax system than in a system of retail sales taxes or VATs. When individual consumers file an annual tax return, the government has a picture of their overall financial circumstances and can tailor tax breaks accordingly. ${ }^{111}$ With retail sales taxes, however, it is difficult for the government to direct individual benefits. When consumers purchase a good, the cash register does not know whether a person's income will be high or low for the year. The individuals themselves may not even know, particularly if the purchase is made in January and their income fluctuates from year to year. Although a number of schemes could be implemented, none is simple or efficient. ${ }^{112}$

the full cost of capital purchases. Rather, the firm can deduct an amount each year that represents depreciation of the capital asset. This approach mirrors the treatment of capital purchases under the current income tax. Finally, if a VAT does not allow any deduction for capital equipment, the resulting tax base approximates gross national product rather than consumption or income. For a description of these three types of VATs, see 1984 TREASURY REPORT, supra note 106, at 5-7.

${ }^{109}$ The value-added tax, which was pioneered in Denmark and France in 1967 and 1968, is now a condition for membership in the European Union, and has been adopted by more than 100 countries throughout the world in Asia, Central and Eastern Europe, Central America, Africa and the Caribbean. See Sijbren Cnossen, Global Trends and Issues in Value Added Taxation, 5 INT'L TAX \& PUB. Fin. 399, 400, 415 (1998); see also Weidenbaum \& Christian, supra note 73, at 8 (describing the widespread use of the VAT throughout the world). The description provided in this article represents an ideal VAT. In practice, however, the contours of an ideal VAT are honored only in the breach, a fact that leads to far more economic distortion than if the VAT were implemented at its best. See Cnossen, supra, at 413-14.

${ }^{110}$ See supra text accompanying notes 85-87.

111 Similarly, in a cash-flow consumption tax, the government at least has a picture of taxpayers' wages if not a full picture of their overall wealth.

${ }^{112}$ For example, the government could issue tax cards based on the individual's financial circumstances the year before. The cards could contain bar codes assigning different levels of taxes. This would require that individuals track their income, a requirement that consumption taxes should eliminate. In addition, any type of system that allows some citizens to purchase items at lower costs than other systems is subject to fraud. 
The problem is even more intractable with VATs. In a VAT, the tax is already embedded in the price of the good. When farmers pay tax on the wheat they grow, the government cannot know whether the wheat will be purchased by someone who is poor or someone who is wealthy. The government could try to exempt certain goods such as bread and milk on the theory that these goods are important to the survival of poor taxpayers. This approach, however, can create great complications and distortions in a VAT system. ${ }^{113}$ For example, should the government exempt all wheat or only wheat going to bread? If the government wants to exempt only wheat going to bread, the firms must have a system to verify who they are and how the product will be used, and the government must engage in enforcement efforts. Before long, the simplicity advantages of a consumption tax can dissipate.

Exempting certain goods from taxation also is a highly inefficient way to relieve the tax burden on the poor. Even if the government exempts tax on simple bread and milk, all consumers who buy those goods will receive a benefit. The wealthy receive the tax break as well as the poor. Thus, the government must spend a lot of money in the form of a tax break to everyone in order to achieve the narrow benefit of a tax break to the poor. This is not the height of efficiency for tax policy.

Cash-flow consumption taxes can be tailored to address regressivity concerns more easily than retails sales taxes or VATs. With a cash-flow consumption tax, individuals file annual tax returns listing their wages and net changes in qualified savings accounts. These annual returns give taxing authorities some information about an individual's economic circumstances, even if it is not a full picture of that person's overall wealth. Taxing authorities can inject some progressivity by applying a higher tax rate to those who have greater wages and withdrawals.

Cash flow consumption taxes, however, are more complex than VATs or retail sales taxes, at least for individual taxpayers. In a cash-flow consumption tax, individuals must still file annual returns. More importantly, individuals must wade through issues concerning which investments count as "qualified" investments, must account for gains and losses in those investments that don't qualify, and must track net changes in investment accounts. In fact, many analysts be-

113 See 1984 TREASURY REPORT, supra note 106, at 39-46 (describing the choices of zero rating and exemption as approaches for easing VATs on certain products). 
lieve that the record-keeping requirements of cash-flow consumption taxes would make them very difficult to administer. ${ }^{114}$

In contrast, in a VAT or retail sales tax, the more complicated issues are handled by businesses. Such entities already engage in keeping extensive records and making accounting judgments and are far more efficient at it than individuals. ${ }^{115}$ In short, a cash-flow consumption tax provides an easier avenue for identifying individuals and responding to individual circumstances although the resulting system is more complex than other consumption taxes. Once again, progressivity comes at the price of increasing complexity. ${ }^{116}$

\section{The Modern Consumption Tax Proposals}

The modern consumption tax proposals that are receiving so much attention are all variations on the consumption VAT. These proposals are the Flat Tax, the X Tax, and the McClure/Zodrow hybrid taxes.

As this section will illustrate, the modern consumption tax proposals all begin with a subtraction method VAT. Businesses calculate their sales for the year, subtract all purchases and expenses incurred that year including purchases of capital equipment, and pay tax on the remaining amount. The remaining amount represents the value added at that level of the production and distribution process, that is, the value added by the firm in the form of profits and the value added by the workers in the form of wages. The modern proposals then modify the VAT by having individuals, rather than businesses, pay tax on wages. The proposals vary in terms of whether there is a single tax rate or graduated rates. Finally, the Hybrid Consumption Tax also varies the treatment of borrowing for businesses.

114 See RosEN, supra note 73 , at 451.

115 See Slemrod, supra note 90, at 382 (noting that the secret to the simplicity of VATs is that they allow most or all of the complicated issues to be handled at the most efficient point-the business).

116 The difficulty of trying to design a workable cash-flow consumption tax is evident in the so-called USA tax proposal. The proposal is a cash-flow consumption tax plan that has been introduced into Congress, and the acronym stands for "unlimited savings account." After the bill was introduced, one scholar described how clever taxpayers could exploit details of the bill to avoid paying any taxes at all. See Martin D. Ginsburg, Life Under A Personal Consumption Tax: Some Thoughts on Working, Saving and Consuming in Nunn-Domenici's Tax World, 48 NAT'L TAX J. 585, 585 (1995). 


\section{Operation of Proposals}

The Flat Tax gets its name from the fact that it has no graduated rates. All firms and citizens pay the same rate of tax. ${ }^{17}$ Under the Flat Tax, firms calculate their sales for the year and subtract the cost of all purchases made that year, including capital expenditures. ${ }^{118}$ This is what a firm would do under a subtraction VAT. There is one major difference, however, between the Flat Tax and a VAT. As described above, a standard VAT taxes wages and profits, the value added by the firm and the value added by the workers. With the Flat Tax, however, the firm does not pay taxes on the workers' wages. Rather, workers file a year-end tax return paying taxes on their wages. $^{119}$ Why go to the trouble of extracting wages from the calculations of a VAT? It allows the government to individualize taxes and inject progressivity. ${ }^{120}$ For example the Flat Tax, as introduced by Armey and Shelby, exempts an initial amount of wages based on how many dependents a taxpayer claims. A family of four, for example, pays no tax on the first $\$ 31,400$ of wages. Thus, with the design of the Flat Tax, the government can help lower-income taxpayers with minimal complication. ${ }^{121}$ Most of the complicated issues of line-drawing and record-keeping are handled at the firm level. Although individuals have an obligation to file returns, the returns contain nothing more than wage information. As a result, the Flat Tax offers a method of approaching regressivity problems while preserving simplicity and economic stimulation.

The Bradford X Tax follows the basic design of the Flat Tax. ${ }^{122}$ Like the Flat Tax, businesses pay a tax identical to a VAT except that wages are excluded. Individuals pay tax on their wages. In contrast to the Flat Tax's single rate, however, the $\mathrm{X}$ Tax has graduated rates on wages. Thus, individuals pay progressively higher rates on their taxable wages as their wage level increases. Firms pay tax at the highest rate applicable to wages. ${ }^{123}$

117 See HALL \& RABUSHKA, supra note 2, at 59, 65 (proposing one rate of $19 \%$ for businesses and individuals).

118 See Charles E. McLure, Jr., The Simplicity of the Flat Tax: Is It Unique?, 14 AM. J. TAX POL'y 283, 286 (Fall 1997).

119 See DAVId F. BRADFORd, Fundamental Issues IN Consumption TAXATION 8 (1996).

120 See id.

121 Despite the initial wage exemption, simulations suggest that if we shift to the Hall/Rabushka Flat Tax, those at the very top still will reap greater benefits than everyone else. See supra note 85.

122 This description of the X Tax is found in Altig et al., supra note 1, at 575. 
Finally, McLure and Zodrow have proposed a Hybrid Consumption Tax. The Hybrid Tax begins with the same approach as the Flat Tax but adds graduated tax rates for individuals. ${ }^{124}$ In addition, McLure and Zodrow alter the treatment of borrowed funds for businesses. $^{125}$

\section{Borrowing Under the Modern Proposals}

Under the Flat Tax, individuals only pay tax on wages. Thus, when an individual borrows money to mortgage a house or finance a car, the transaction is ignored for tax purposes. Similarly, when a business borrows money, the transaction is ignored for tax purposes. Although businesses deduct expenses under the Flat Tax, the cost of borrowing funds does not count. Businesses do not get to deduct anything for payments of interest and principle under the Flat Tax. ${ }^{126}$ In short, when an individual or a business borrows money, the transaction has no tax consequences for the borrower. ${ }^{127}$

subsidy to wages. See Altig et al., supra note 1, at 575.

${ }^{124}$ It takes some translation of terms to understand the McLure/Zodrow tax. McLure and Zodrow explain that their hybrid consumption tax is a combination of yield-exemption tax (YET) treatment for individuals and consumed income tax (CIT) treatment for businesses. See McLure \& Zodrow, supra note 2, at 88 . They define YET treatment for individuals as a Business Transfer Tax modified so that individuals, rather than businesses, pay tax on wages above a certain level. See id. at 87-88. They also define a Business Transfer Tax as a subtraction method VAT. Id. at 87. Thus, the McLure/Zodrow approach begins with the same structure as the Hall/Rabushka Flat Tax: a subtraction method VAT modified so that individuals rather than businesses pay tax on wages.

McLure and Zodrow modify this Flat Tax structure by adding graduated rates. See id. at 88 (Hall/Rabushka Flat Tax differs from the YET by having a single rate for wages rather than graduated rates.) See id. at 72, 88 (authors assume graduated rates on the individual side).

Finally, McLure and Zodrow add CIT treatment for businesses. The authors define CIT treatment as taxing proceeds of borrowing, debt repayment, and interest income while allowing deductions for making loans, repaying debt principle, and paying interest expenses. See id. at 88.

125 See id. at 70-73. When McLure \& Zodrow call their plan a hybrid tax, they are not suggesting a hybrid between a consumption tax and an income tax. Rather, the authors are noting a blending of two different approaches to consumption taxation in the treatment of borrowing.

126 See HALL \& RABUSHKA, supra note 2, at 109.

127 See id. Absent special rules, the transaction also would have no consequences for the lender. Interest, like all other earnings on investments, is not taxable under a consumption tax. Thus, when a bank lends money, the bank does not pay tax on the interest received.

Banks also obtain funds from depositors, other banks, and the Federal Reserve in exchange for interest payments. Absent special rules, these interest pay- 
In theory, a consumption tax could classify borrowing as a taxable event. The government could treat borrowed money as taxable on the theory that the borrower will spend the money on consumption. Thus, when an individual mortgages his or her house and receives money from the bank, that money could be taxed. Similarly, when the individual repays the bank with principle and interest, the payment represents money that the individual can no longer spend. Thus, the individual could deduct principle and interest payments. This would be a cash-flow approach to the treatment of borrowing. ${ }^{128}$ Mclure and Zodrow point out that the Flat Tax approach to borrowing makes sense for individuals. Taxing individual taxpayers on their borrowings would eliminate the exquisite simplicity of the Flat Tax. Individuals would be required to keep track of funds received through borrowing as well as interest and principle payments. Thus, taxing borrowing for individuals would add complexity and reintroduce record keeping. ${ }^{129}$

The picture is a little different from the business side. Businesses already track borrowing. In addition, by ignoring business borrowing, the government loses a lot of revenue and creates oppor-

ments also would be ignored for tax purposes just as any business borrowing is ignored under the Hall/Rabushka Flat Tax. A problem arises, however, because banks earn a profit on the spread between the interest paid to depositors, for example, and the interest earned from homeowners. It would seem unfair to allow the financial sector to escape taxation. See McLure \& Zodrow, supra note 2, at 75 . In addition, the interest spread represents the fact that the bank delivers services to its customers, both depositors and borrowers. See HALL \& RABUSHKA, supra note 2, at 74. Services should be taxed under a consumption tax. Thus, without some special arrangements, the bank could end up providing services while escaping taxation.

Some consumption tax advocates have proposed that taxes like the Hall/Rabushka Flat Tax include a separate tax on the financial sector. See McLure \& Zodrow, supra note 2, at 75 (arguing that a separate tax on the financial sector would be complex and difficult to design in a way that would be neutral between financial and nonfinancial institutions). The Hall/Rabushka Flat Tax itself contains special rules that apply to the financial industry and provide for taxation of financial intermediation services. See, e.g., H.R. 1040, 105th Congress $§ 11(\mathrm{e})$ (1997) (Special Rules for Financial Intermediation Service Activities); see also Hall \& RABUSHKA, supra note 2, at 73-75 (recommending special rules for banks and life insurance companies).

128 The lender would be treated under cash flow rules as well. Thus, when a bank loaned money, the outflow of funds would be deductible as an expense. The bank would then pay tax on principle and interest received from those who borrowed the money.

129 Taxing only an individual's wages, however, would not require record keeping, at least not for individual taxpayers. Employers already track wages and give each employee a year-end form showing all wages. 
tunities for tax avoidance. ${ }^{130}$ In response to these problems, the authors propose that the government ignore borrowing for individuals but adopt a cash-flow approach for businesses. Thus, when a firm borrows money, the dollars received are taxable. When the firm pays principle and interest, the payments are deductible as expenses. ${ }^{131}$ In short, the Mclure/Zodrow Hybrid Tax follows the Flat Tax with the exception that the government taxes business borrowing on a cash flow basis and taxes individual wages at graduated rates. ${ }^{132}$

\section{How THE MODERN PROPOSALS FAIL TO TAX INDIVIDUAL CONSUMPTION}

The Flat Tax, The X Tax, and the McLure/Zodrow Hybrid Tax are all consumption taxes. Thus, to have individual taxation, the plans must have the effect of taxing people for the amount they consume.

The proposals, however, have one particular feature that, by itself, will move the system away from individual taxation. This feature is the immediate deduction of capital expenditures. Regardless of other characteristics of the proposals, this feature alone casts serious doubt on the ability to achieve individual taxation. This result holds true under varying tax incidence assumptions. ${ }^{133}$

The following section describes the distortionary effects of immediate expensing under the modern proposals. These potential ef-

130 See McLure \& Zodrow, supra note 2, at 75-77. Such tax avoidance schemes ordinarily are not available to individual taxpayers.

131 When a firm lends money to a business, for example, when a bank makes a business loan, the McLure/Zodrow plan provides analogous treatment. The bank gets a deduction for the outflow of dollars. When the bank receives payments of principle and interest, those payments are taxed. See id. at 74 tbl.1.

132 The authors also have proposed a variant on this approach for developing countries. See George R. Zodrow \& Charles E. McLure, Jr., Implementing Direct Consumption Taxes in Developing Countries, 46 TAX L. REV. 405, 457, 471 (1991).

133 Conclusions about the incidence and shifting effects of levying a tax on a firm, whether it is a corporate income tax, a payroll tax or a value-added tax, are subject to considerable disagreement and uncertainty in the field of public finance. See RoSEN, supra note 73, at 278 (noting uncertainty with respect to corporate tax incidence); James Porterba, Comments on Chapter 2: The Distribution of the Tax Burden, in Modern PUBlic FINANCE 50-52 (John M. Quigley \& Eugene Smolensky eds., 1994) (describing unanswered questions in the current incidence literature). Moreover, incidence study results depend critically on the underlying models, and the models and assumptions used in different studies vary considerably. See RosEN, supra note 73, at 278; Laurence J. Kotlikoff \& Lawrence H. Summers, Tax Incidence, in 2 HANDBOOK OF PUBLIC ECONOMICS 1043-44 (Alan J. Auerbach \& Martin Feldstein eds. 1987). 
fects have not been explored in the literature on either VATs or the modern proposals. The section first explores the effects of immediate expensing under the assumption that when a firm pays its business-level VAT under the proposals, the tax is fully shifted to consumers. The section next explores the effects of immediate expensing under the opposite assumption: that the firm-level VAT under the proposals is analogous to a profits tax and will be fully absorbed by the firm. Under either assumption, immediate expensing creates distortions such that the amount of tax a consumer pays will not match the consumption value of the item consumed. This article does not try to examine all possible incidence effects of the modern proposals and other forms of consumption taxes. Rather, the article focuses on one particular distortionary effect that has not been explored in the literature and would apply only to the modern proposals. In addition, the article tries to avoid the uncertainty surrounding the shifting effects of any tax levied on a firm by considering assumptions at either end of the spectrum.

\section{A. Immediate Expensing if the Firm-Level Tax is Fully Shifted}

Under the modern proposals, the VAT is separated into a portion paid by the firm and a portion paid by the workers. Leaving aside the portion that workers pay, in order to have individual taxation, consumers must at least end up bearing the burden of the tax paid by the firm.

A number of economic studies assume that a broad-based, consumption VAT is fully shifted to consumers. ${ }^{134}$ In that case, any VAT paid by a firm will eventually be paid by the consumer who

134 See, e.g., StePhen P. DRESch, AN-LOH LIN \& DAVId K. Stout, Substituting A VAlue-Added TAX For the CoRPorate InCOME TAX 11 (1977); Henry Aaron, The Differential Price Effects of a Value-Added Tax, 21 NAT'L TAX J. 162, 167 (1968) (noting that under classic assumptions, the corporate income tax is not fully shifted while the value-added tax is fully shifted). Dresch et. al. describe the assumptions behind the model of full forward shifting for a consumption VAT:

The assumption of an appropriately flexible, monetary policy is required to support the assumed patterns of VAT shifting. More generally, under the assumption of profit-maximizing behavior on the part of producers and traders, monetary and fiscal policies are assumed to be compatible with maintaining the original (preVAT) level of real income along with proportionate changes in all prices and unchanged net-of-VAT demands for all commodities, with effectively complete forward shifting. 
purchases the final good. ${ }^{135}$ Thus, as long as each firm pays tax that reflects the value added to the good at the firm's level, the final consumer will pay a tax that reflects the total value of the good. ${ }^{136}$

Immediate expensing, however, will cause distortions in the level of tax paid each year by the firm. This problem occurs because the modern proposals would not match the costs of producing a particular item with the tax on that item. Rather, the system is designed to tax sales for the year and deduct costs for the year, regardless of whether those costs relate to the products sold. Although this approach is vastly simpler than matching costs with inventory sold, it distorts the amount of tax applied to each item.

Specifically, each firm's tax return begins with the total amount of sales for the year. The firm then subtracts its purchases, including all capital purchases and expenditures. Such purchases, however, may be used in products sold in other years or may never be used at all. Nevertheless, the firm takes a full deduction for the cost of those purchases in the year of purchase. ${ }^{137}$

As a result, a firm making the same product, year in and year out, may have different taxes from each year. For example, when a firm purchases a new plant full of equipment, the firm will deduct the full amount of the purchase that year. The firm's taxable profits for the year will, therefore, be quite low. The low taxable profits reflect the fact that the firm is able to deduct some of the future costs of doing business today. In future years in which the firm does not continue making capital purchases, the firm's taxable profits will rise. Thus, the firm's taxes will vary from year to year depending on the level of capital purchases rather than on the value added to the items sold that year.

If the firm is able to pass the tax on to consumers, consumers will bear different tax burdens on the same goods purchased in different years. The government will thus undertax products sold in some years and overtax products sold in other years.

135 The VAT is a multi-stage tax. Thus, the purchaser at any given stage is not necessarily the ultimate consumer. This analysis assumes the most optimistic vision of tax shifting: Purchasers at each level pass the tax smoothly on to the next level so that the final consumer bears the total burden of the taxes paid along the way.

136 Note, again, that I am leaving aside the wage portion of the good.

- 137 Full expensing is consistent with the underlying logic of a consumption tax. After all, consumption taxes are intended to tax consumer spending while encouraging savings and investment. Capital purchases can be viewed as investments, which, therefore, should not be taxed. Regardless of the merits of this argument, immediate expensing distorts the amount of tax levied on each individual product. 
One could argue that the firm will choose to equalize prices over the life of all input and capital purchases. According to this view, the firm will take advantage of the tax deduction in early years, but spread those effects over the expected life of whatever is purchased. In other words, the firm will take an immediate deduction for the costs but amortize the effects. This would require, however, a high degree of precision in predicting future production schedules, future purchasing and investment levels, future sales levels, and the useful life of assets. Even if one assumes that firms choose to amortize effects, one should expect deviations from perfect foresight which would create variations between the tax paid on an individual item and the consumption value of that item.

More importantly, a rational firm would know that the future is murky. Products become obsolete, new competitors materialize, technological developments lower costs, brand loyalties strengthen, and tax regimes change. Thus, a firm may take advantage of the opportunity to decrease prices and increase market share, even at the risk of possible price increases in the future. As a result, years of lower firm-level taxes will mean years of lower consumer-level taxes such that the amount of tax a consumer pays will not match the value of the item consumed.

The examples above describe how consumers who purchase the same good from the same firm in different years can have different tax burdens. The modern proposals also will lead to varying rates of taxation between firms and between industries. Firms and industries that are experiencing a high ratio of investment to value added will face lower taxes than those that are experiencing lower ratios. Thus, firms will bear relatively less tax burden when they are in an expansion period, either because they are getting started or because their business or industry is growing. In contrast, firms and industries that are not growing will receive less of a comparative tax advantage. One could argue that it is appropriate for the tax system to disfavor firms in the most sluggish industries and at the slowest points in their development. Regardless of whether this is true, it still has the effect of moving the system away from individual taxation. If effective taxation varies among firms and industries and the taxes are passed onto consumers, consumers are not properly taxed for the value of what they consume.

In short, if the aim of a consumption tax is to tax consumers on the value of the item they consume, immediate expensing under the modern proposals will have a distortionary effect. Using the assumption that taxes are passed on to the consumer, the amount of $\operatorname{tax} a$ 
consumer pays on each item will not match the consumption value of the item. ${ }^{138}$

\section{B. Immediate Expensing if the Firm-Level Tax is Not Ordinarily Shifted}

The analysis above assumed that the firm-level tax is fully shifted on to consumers. Suppose the firm-level tax is not fully shifted to consumers-would immediate expensing still produce distortions? The following section explores a new set of assumptions under which one would ordinarily expect a firm to absorb the full burden of the tax.

At the most general level, a VAT is composed of the value added by the firm and the value added by the workers. Under the modern proposals, however, individuals, rather than firms, pay tax on the value added by workers in the form of a wage tax. Thus, under the modern proposals, the firm-level tax is levied only on the value added by the firm, in other words, the returns to the firm.

At this point, it is important to note that I am discussing the returns to the firm in terms of economic theory. ${ }^{139}$ Thus, the returns to

${ }^{138}$ It is possible that although the tax burden on each individual item is distorted, a consumer's overall tax burden correlates appropriately. In other words, it is possible that in a consumer's overall basket of goods, the amount of overtaxation on items will roughly match the amount of undertaxation of items. Although this would require some interesting coincidences of effects, it may be useful to consider such a possibility in modeling the distortions described in this article.

${ }_{139}$ Excess profits could only exist in the case of a firm that has some degree of market power. Perfect competition eliminates all excess profits and yields only ordinary returns, which are equal to the opportunity costs of the capital. See Robert S. Pindyck \& Daniel L. Rubinfeld, Microeconomics 273 (5th ed. 2001). For an extensive explanation of the behavior of firms in perfect competition, see N. GREGORY MANKIW, PRINCIPLES OF ECONOMICS 283-301 (1998).

A number of scholars suggest that many American firms have at least some market power and therefore some ability to set prices. For example, Areeda notes that "[p]erfect competition is an analytic tool that neither describes most markets nor provides a normative ideal. Attempting to bring it about would be futile, overload the legal system, impair efficiency and innovation, and increase to intolerable levels the litigation costs and sanctions for desirable business conduct." PHILLIP AREEDA ET AL., ANTITRUST LAW § 1736c2 (1996); see also Robert E. Hall, The Relation Between Price and Marginal Cost in U.S. Industry, 96 J. POL. ECON. 921, 946 (1988) (most obvious explanation for widespread finding of price far in excess of marginal cost is monopoly power in American product markets due to oligopoly and product differentiation); BRADLEY R. SCHILLER, THE ECONOMY TODAY 596-99 (3d ed. 1986) (demonstrating that price-leadership is widespread); JEAN TIROLE, THE THEORY OF INDUSTRIAL ORGANIZATION 277 (1990) (noting that, in practice, the assumption that firms produce a homogeneous product and that no firm can raise its price above marginal cost without losing its entire market share is unlikely 
the firm are composed of the firm's ordinary profits plus any excess profits. I am not describing what is taxed by the current American corporate income tax. Although many think of the corporate income tax as taxing returns to the firm, the system contains features that distinguish it from simple taxation of returns. Studies that evaluate shifting of the corporate income tax, therefore, are relevant for my purposes only when the assumptions mirror taxation of ordinary or excess profits.

In the section above, I chose assumptions that would ordinarily suggest full shifting of the firm-level tax. In the section below, I choose assumptions that would ordinarily suggest no shifting of this tax. An extreme set of assumptions with this latter result would posit a firm-level tax completely analogous to an excess profits tax. In that case, conventional wisdom would suggest that the firm will maintain all prices at pretax levels and absorb the entire burden of the tax.

The following section first describes the conventional wisdom on excess profits taxes. It then explains how the modern proposals would operate such that distortions would occur even under these assumptions. In short, this article does not attempt to explain all possible incidence assumptions but merely to show that, using two sets of assumptions at opposite ends of the spectrum, immediate expensing will produce distortions.

\section{Conventional Wisdom on Profits Taxes}

As described above, the firm-level tax is levied on the returns to the firm. The returns to the firm are composed of ordinary profits and excess profits. In the case of a tax on excess profits, conventional wisdom suggests that the firm will absorb the entire burden of the tax, and no price shifting will occur. Thus, to find a set of assumptions under which one would ordinarily expect no shifting, one could theorize that the firm-level tax under the modern proposals is analogous to a pure excess profits tax.

to be satisfied); Richard Schmalensee, On the Use of Economic Models in Antitrust: The ReaLemon Case, 127 U. PA. L. REV. 994, 1015 (1979) (observing that markets almost always contain goods that are not perfect substitutes); $c f$. Robert Pitofsky, Antitrust in the Next 100 Years, 75 CAL. L. REV. 817, 825-26 (1987) (criticizing scholars for failing to adequately recognize market power based on product differentiation). In addition, price variations may exist even among identical products. See F. M. SchERER \& DAvid Ross, Industrial MARKET STRUCTURE AND ECONOMIC PERFORMANCE 574 (3d ed. 1990) (noting that substantial price differences persist in consumer goods markets even for the same goods within the same geographic area). 
Conventional wisdom on the effects of excess profits taxes suggests that the tax would be entirely absorbed by the firm in the form of lower profits. ${ }^{140}$ The general intuition on profit taxes can be explained in the following manner. Prior to imposition of the tax, the firm has chosen a price that maximizes profit. For example, assume that the profit-maximizing price is $\$ 100$ and the profit is $\$ 10$. At that price point, the firm makes more profit than at any other price point.

The profit tax will reduce the amount of the profit by the percentage of the tax. Thus, for example, with a $10 \%$ tax, the producer keeps only $90 \%$ of the profit. We assumed, however, that the $\$ 100$ price yielded the highest profit. Ninety percent of the highest profit is still better than $90 \%$ of any other profit. Thus, the producer cannot increase its profit by changing its price, and the price to the consumer will remain the same. ${ }^{141}$

\section{Conventional Wisdom Applied to the Modern Proposals}

As described above, conventional wisdom explains that when the government levies taxes on a firm's excess profits, the firm will absorb those taxes in the form of lower profits. In contrast, the following section identifies a price effect that neither the literature on excess profits taxes nor the literature on the modern proposals has previously described. This price effect flows from immediate expensing. In light of this effect, the amount of tax a consumer pays on each item will vary with the level of the firm's investment rather than with the value of the item purchased. Thus, even under the assumption that the tax is analogous to an excess profits tax, immediate expensing will move the system away from individual taxation.

The price effect occurs because immediate expensing under the modern proposals can cause prices to fall in years in which the firm incurs heavy investment expenditures. As a result, consumers who buy the same product in different years may pay different prices based on the firm's level of investment. The logic is the following: Under a VAT, the taxing authority collects tax on a product in a piecemeal fashion, a little bit at each stage of the production and distribution process, in a manner that reflects the value added at that

140 See RoSEN, supra note 73, at 269-70.

141 See id. at 290. The following equation shows the conventional view that profit taxes are borne entirely by the firm. Suppose a firm has price $\mathrm{P}$ and variable costs of $\mathrm{C}$ and an output quantity of $\mathrm{Q}$. To simplify the calculations, assume further that there are no fixed costs. The firm's gross margin or profits will be $G_{0}=(P$ C)Q. The tax rate will be $t(G)$. Thus the new profits will be $G_{1}=(1-T)(P-C) Q$. Whatever price maximizes $G_{0}$ will also maximize $G_{1}$. For a variation on this equation, see $i d$. 
stage. To avoid double taxation, the firm must get credit for value that other firms have added to the product because the government has already taxed that value. Thus, when a firm calculates its VAT, the firm subtracts the cost of all inputs into the product. When a firm purchases the inputs for a product, therefore, the firm prepays tax for the value added at prior stages in the production process. The firm will get credit for the prepaid tax when the product is sold. ${ }^{142}$ The firm must have a tax liability, however, to absorb the credit for the prepayment. If there is no tax liability to absorb the credit, the firm, which has prepaid taxes, loses the use of that money for its business operations until the credit is absorbed. ${ }^{143}$ The firm could, of course, replace the money by borrowing, but the firm would be saddled with interest costs.

The government could attempt to address this problem by paying interest on the tax credit. Under the Flat Tax, when a firm uses tax credits that it has carried forward, the government does pay interest. $^{144}$ The amount the government pays, however, is unlikely to match the firm's cost of replacing the funds. For example, under the Flat Tax, the government would pay interest on tax credits at roughly the rate earned by investing in bank CDs or Treasury Bills. ${ }^{145}$ The Flat Tax authors note, for example, that the rate for 1995 would have

142 The same principle applies to capital investments as well as physical inputs. When a firm purchases a physical input such as flour, the cost of the flour includes taxes already paid by other firms on the value they added to the product. The same will be true when a firm purchases capital equipment such as a piece of machinery. Even when a firm builds a new factory, for example, the cost of the factory will include taxes paid by suppliers of the bricks and mortar as well as taxes paid by the contractor on the value of his or services.

${ }^{143}$ The problem occurs in part because by collecting the tax on a product piecemeal, the government collects tax on portions of goods that may never be completed and may never be sold to consumers. (One could argue that the tax punishes those who make goods that are never consumed. There may be some economic logic, however, to discouraging those whose productive enterprises ultimately will be unsuccessful.)

144 See HALl \& RABUSHKA, supra note 2, at 64.

145 See id. (noting that the government would pay interest at "market rates" which the authors define as $6 \%$ for 1995); see also The Federal Reserve Board, Statistics: Releases Historical Data, at http://www.federalreserve.gov/releases/H15/data/a/cd6m.txt (released Jan. 28, 2002) (6- month CDs in 1995 paid 5.98\%); The Federal Reserve Board, Statistics: Releases Historical Data, at http://www.federalreserve.gov/releases/H15/data/a/tcm1y.txt (released Jan. 28, 2002) (1-year Treasury Bills in 1995 paid 5.94\%). 
been $6 \%{ }^{146}$ Firms will be unable to borrow money at such low rates. $^{147}$

These interest rate discrepancies may particularly occur for the firms that are likely to have large tax credits. In order to have a tax credit, the firm's profits, as measured by its value added, must be lower than its costs including investments. Such firms are likely to be in a startup phase or in a period of expansion, periods in which they are likely to face higher borrowing rates. ${ }^{148}$

Thus, although the firm could replace the prepaid taxes by borrowing, the cost of replacing the funds is likely to be higher than the interest received from the government. This discrepancy gives the firm an economic incentive to get its prepaid tax back today. In order to recover the prepaid tax, the firm must generate more tax liability. The best way to generate more tax liability is to generate more revenue by selling more products. ${ }^{149}$ At the current price, however, the

${ }^{146}$ See HALL \& RABUSHKA, supra note 2, at 64.

${ }^{147}$ For example, the prime rate (the rate at which banks offer loans to their best customers) was $8.83 \%$ in 1995 , a significant distance from the $6 \%$ rate the government would pay. See The Federal Reserve Board, Statistics: Releases and Historical Data, at http://www.federalreserve.gov/releases/H15/data/a/prime.txt (released Jan. 28, 2002). In addition, many firms would not qualify for prime-rate lending.

${ }^{148}$ In the startup phase, a firm has no experience in its new. setting. Lack of experience increases the risk for lenders who will respond by charging higher loan rates. Similar issues can arise for existing firms if the firm is expanding into new products or new markets. See David S. Evans \& Boyan Jovanovic, An Estimated Model of Entrepreneurial Choice under Liquidity Constraints, 97 J. POL. ECON. 808,809 (1989) (noting liquidity constraints for companies in initial stages due to capital market failures).

Alternatively, a firm's profits might be below its costs if it were in a period of decline. A firm in decline also would be less attractive to lenders and would face higher interest rates.

${ }^{149}$ The firm need not necessarily increase profit in order to increase its tax liability for the following reason: The firm pays tax based on its revenues less costs and capital expenditures. When the firm makes a capital investment, it is essentially buying inputs in advance that can be used in the production of future products. Suppose the firm chooses to increase the amount of products it sells for the year. Selling more products will generate more revenue. The firm, however, has already purchased some of the inputs for the additional products sold. To the extent that the firm has already purchased these inputs, the firm will not incur any additional costs. If the firm incurred no additional costs for additional sales, the entire revenue from each sale would be taxable. In that case, all revenue earned on each sale would go to absorbing the tax credit. In the more likely scenario, additional sales will generate some additional costs that will reduce the taxable revenue. The key point, however, is that for the purposes of absorbing the tax credit, the relevant figure is not profit, but revenue less some portion of the costs. 
market is already absorbing all of the product it can. The firm will therefore lower its price to increase sales.

The modern proposals exaggerate this effect in the following fashion. Firms will have an incentive to lower their prices in years in which they have a tax credit. A firm will have a tax credit when the firm's investment exceeds the value added at that stage. ${ }^{150}$ In calculating value added at that stage, however, the modern proposals subtract wages, the value added by the workers. ${ }^{151}$ Thus, value added will be lower under the modern proposals than under an ordinary VAT. Given that labor costs across all products average $20 \%$ of total costs, the difference will be substantial. ${ }^{152}$ Under the modern proposals, therefore, a firm need not have such a high level of investment in order to zero out its tax liability for the year and incur a tax credit.

In sum, under even the more extreme assumption that the firmlevel tax operates like a profits tax, immediate expensing can lead to price effects that will cause consumers to pay differing amounts of tax based on the firm's level of investment. Given that investment levels for any given firm are likely to vary substantially across time, ${ }^{153}$ there may be significant variation in prices paid by different

150 The simplest way to see this is to note that the firm would owe tax on the value added but would get to deduct the investment costs first. Thus, the tax liability will disappear when the investment costs are as great as the value added. A firm will have a tax credit when investment exceeds value added at that stage.

Also, the firm's investment could be in the form of capital expenditures. The firm could also choose to purchase large amounts of physical inputs in advance, perhaps because the price is attractive or because the firm anticipates shortages. Firms, however, may not overpurchase inputs in amounts large enough that the impact of such an expenditure can be equated with the impact of investments through capital expenditures. Capital expenditures are therefore more likely to produce the more significant distortions in a firm's life.

${ }^{151}$ Recall that under the modern proposals, the government taxes individuals rather than firms for the value of labor so that the government can levy lower taxes on those who have lower wage levels.

${ }^{152}$ Labor's share of all factor costs can range from a low of about $6 \%$ in petroleum refining to a high of about $51 \%$ in trade. Labor costs across all industries as a whole are roughly $20 \%$ of total costs. See M. Ishaq Nadiri \& Theofanis P. Mamuneas, Contribution of Highway Capital to Industry and National Productivity Growth 38 (Sept. 1996), www.fhwa.dot.gov/reports/growth.pdf (citing labor data from NIPA, the Census of Populations and the Current Population Survey and output data from the Bureau of Labor Statistics and the BEA); see also United States Department of Labor, Bureau of Labor Statistics, News Release, Employer Costs for Employee Compensation, tbl.5 (Mar. 2001), http://stats.bls.gov/news.release/ecec.t05.htm (total compensation for workers across all industries is roughly $20 \%$ of total costs).

153 See John C. Haltiwanger, Understanding Aggregate Fluctuations: The Importance of Building from-Microeconomic. Evidence? ONATIONAL BUREAU OF 
consumers across time. If the aim of a consumption tax is to tax consumers on the value of the item consumed, immediate expensing again moves the system away from this goal.

\section{Would Immediate Expensing Move the System Towards General Taxation?}

As described above, the effects of immediate expensing would move the system away from individual taxation. Would immediate expensing move the system towards general taxation? In other words, would the proposals tax all of the consumption throughout society as a whole, and would the burden of the tax fall on those involved in consumption?

Using the assumption that firms fully shift the firm-level VAT onto consumers, some consumers would pay more than their share of tax on a particular item while others would pay less. As a result, the tax system would capture the full amount of the base from consumers as a whole, although it would not necessarily match each consumer's tax bill to the value of that person's consumption. Thus, immediate expensing would move the system towards general taxation.

This result would not hold true under the assumption that the firm responds to the VAT as it would a profits tax. If the firm-level VAT is analogous to a profits tax, consumers will bear none of the burden in the case of positive taxation and varying amounts of the burden in the case of tax credits. The firm would absorb the remainder of the burden in the form of lower profits. Thus, the burden would fall on firms as well as consumers. Under this assumption, the modern proposals would not fit the definition of general taxation because the burden can fall somewhere other than on those engaged in the activity of consumption. ${ }^{154}$

portance of Building from Microeconomic Evidence, NATIONAL BUREAU OF ECONOMIC RESEARCH REPORTER (Spring 1999), http://www.nber.org/reporter/spring99/haltiwanger.html (recent studies support the view that micro investment dynamics exhibit lumpy adjustment with plant-level investment dominated by large-scale investment spikes).

154 The modern proposals could only fit the definition of general consumption if the definition of the tax base includes both producers and consumers. Part of a consumer's tax may be shifted to other consumers, and part of a consumer's tax may be shifted on to producers of goods for current consumption. Thus, the proposals would result in general taxation of a particular base if the base includes all those involved in current consumption, including both producers and consumers. It may be an interesting exercise to explore the notion of a tax base that includes producers and consumers. Cf. supra note 65 (noting the artificiality of viewing consumption in isolation from the production cycle). 
Moving the system towards general consumption, however, would not solve the problems concerning the gap between the theories underlying the modern proposals and the effects. The only theories that would support a system of general taxation for the new base would be those consistent with a system that does not match an individual consumer or producer's share of the base with that individual's tax. Thus, most nonconsequentialist and weighted welfarist theories would not suffice. Only a pure utilitarian/welfarist theory would suffice, and such a theory would have to be carefully calibrated to account for the incentives' effects of burden shifting.

\section{Other Forms of Consumption Taxes}

The distortions described in this article result from the way in which firms may react to the opportunity for immediate deduction of all capital expenditures under the modern proposals. Other forms of consumption taxes such as cash-flow consumption taxes and retails sales taxes, do not have this feature and thus would not suffer the distortions described in the article. For example, in a classic cashflow consumption tax, there is no firm-level tax. In a retail sales tax, taxes are levied on the price of the product without any calculation of costs and value added. Thus, under other forms of consumption taxes, firms would not have the types of incentives described in the piece that would lead to a distortion of the amount of tax paid by a consumer when compared to the consumption value of the item purchased. This suggests a variation in the effects of different types of consumption taxes that the literature has not identified.

\section{CONCLUSION}

Individual taxation occurs when a tax system correlates an individual's tax bill to that person's share of the tax base. When a system deviates from individual taxation, one should ask how those deviations affect tax burdens for taxpayers who participate in the activity that constitutes the tax base. In addition, one should ask whether the theories offered in support of the tax system depend on individual taxation. If the underlying theories are grounded in individual taxation, the more the system deviates from individual taxation, the less the system can satisfy the foundational logic. If the theories are grounded in individual taxation, and the system deviates from that result, one should ask whether any other tax systems can produce a closer match between the theories and the effects.

The modern tax proposals that are receiving attention in the academic literature would do a poor job of creating individual taxation 
based on the effects of immediate expensing. Most of the theories underlying consumption taxation, however, depend on individual taxation. The extent of deviation is particularly problematic for nonconsequentialist and weighted welfarist theories of consumption taxation. Only simplified welfarism, with its focus on maximizing overall economic growth, could support a system regardless of how well it captures individual consumption.

In short, although the modern proposals offer tantalizing claims of resolving past debates, the theory of individual taxation suggests new problems. Consumption tax advocates who favor the modern proposals must be willing to abandon or rethink many of the theoretical justifications offered in support of consumption taxes.

This article does not try to resolve the classic debates concerning the equity, simplicity, and economic effects of taxing consumption versus income. Rather, the article suggests an additional benchmark for evaluating tax proposals in comparison to their theoretical justifications.

\section{ISSUES FOR FUTURE CONSIDERATION}

Analyzing consumption taxes from the perspective of general and individual taxation highlights variations in the effects of different consumption tax systems and variations in the amount of correlation with the underlying theories of consumption taxes. The same type of analysis could be applied to other types of tax systems, such as income taxes.

For example, as described above, when workers are taxed on their wages, the burden of those taxes may be shifted in whole or in part to owners of firms, depending on the extent to which workers are willing to continue working in the face of a decline in real wages. Income taxes include a tax on wages. Thus, burdens from one portion of an income tax, wage taxes, may be shifted away from those who earn wage income and onto those who earn income from returns to capital. ${ }^{155}$ One could argue, therefore, that this aspect of an income tax system shifts the burden among different income earners thereby creating an aspect of general taxation. An examination of income tax systems may illuminate these and other characteristics that would move the system away from individual taxation.

Thus, an interesting question for future consideration would be the extent to which income tax systems deviate from individual taxation and the extent to which the underlying theories depend on individual taxation. One could then try to compare the deviations of

155 Recall that consumption taxes do not tax investment returns unless those returns are spent on consumption. 
various consumption tax systems with the deviations of income and other types of tax systems to determine which type of system offers the greatest correlation between theory and effects.

As a general matter, the theories presented in this article can be used to highlight the contrast between the individualist arguments we make for a particular tax base and our all too frequent indifference to, or inability to measure, the effects of a tax regime on any individual person. Although the article applies these theories to particular consumption tax proposals, the theories also can be applied to tax policy more broadly. In the end, it is possible that so much of tax theory depends on individual taxation, and yet so little individual taxation occurs, that it is worth rethinking our approach to tax policy on the whole. For example, should we recognize the limitations of tax systems and acknowledge that they are capable of satisfying a far narrower range of theoretical goals? Should we alter our vision of tax theory to focus more on groups or categories and less on individuals? Should we try to develop new types of theoretical goals or different tax system configurations? Or should we simply accept the gap between tax systems in theory and in actual effect?

156 In comparing different tax systems, it would be important to compare them in their ideal forms. Once implemented, any tax system is likely to deviate substantially from its original goals in response to administrative and political pressures. Comparing an idealized system with a system that has been implemented, therefore, would always result in the conclusion that the system in place deviates more substantially from individual taxation. 